\title{
Nature as a treasure trove for anti-COVID-19: luteolin and naringenin from Indonesian traditional herbal medicine reveal potential SARS-CoV-2 Mpro inhibitors insight from in silico studies
}

\author{
Wahyu Eko Prasetyo, Triana Kusumaningsih* and Maulidan Firdaus \\ Department of Chemistry, Faculty of Mathematics and Natural Sciences, Sebelas Maret University, J. \\ Ir. Sutami No.36A, Surakarta, 57126, Indonesia \\ *corresponding author: triana kusumaningsih@staff.uns.ac.id
}

The SARS-CoV-2 has emerged and raised global health emergency namely "COVID-19" pandemic, which infected million people and killed hundreds of thousands of people worldwide since Dec 2019. Since there is no specific drug or treatment strategy and because of its rapid spread all over the world, thus, there is a crucial need to discover effective drug molecules to fight the virus. Employing the newly released $3 \mathrm{CL}^{\text {pro }}$ of SARS CoV-2 crystal structure, we carried out virtual docking screening of selected 49 bioactive phytochemicals from several medicinal plants used in Jamu, the Indonesian traditional

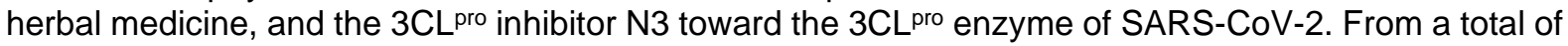
49 bioactive phytochemicals, eleven compounds exhibited good binding affinity against $3 C^{\text {pro }}(-7.2$ to $-8.5 \mathrm{Kcal} / \mathrm{mol})$. Accordingly, only seven phytochemicals fully obeyed drug-likeness properties. Exclusively, Luteolin and Naringenin interacted strongly with both catalytic dyad residues of $3 \mathrm{CL}^{\text {pro }}$ through hydrogen bonds (HBs) and hydrophobic interactions, respectively. Additionally, the pharmacokinetic studies advised that Luteolin and Naringenin possess favourable drug-likeness properties. Furthermore, the density-functional theory (DFT) study was also established to highlight the prominence of this chemical scaffolds. Overall, our study revealed that these two bioactive phytochemicals from Tamarindus indica (Luteolin and Naringenin) and Citrus aurantifolia flavonoids (Naringenin) can be the potential antagonist of $3 \mathrm{CL}^{\text {pro }}$ of SARS-CoV-2.

Keywords: ADMET; COVID-19; DFT; Flavonoids; Jamu; Luteolin; Naringenin 


\section{Introduction}

Currently, the SARS-CoV-2 infection has been speedily escalated worldwide, causing global pandemic called COVID-19, since the first outbreak appeared at the end of 2019 in Wuhan, China ${ }^{1-3}$. This disease is considered to highly contagious, which can be transmitted through respiratory droplets from coughing and sneezing 4,5 . Dramatically, as of 28 November 2020, a total of $62,010,669$ infected cases and 1,449,373 deaths have been reported (www.worldometers.info). Though a series of diagnostic tools are accessible, the availability of vaccines and drugs or special treatments are not yet accessible to combat this new coronavirus ${ }^{6}$. Thereby, it is crucial to design and develop an efficacious antivirals agent along with the discovery of vaccines against SARS-CoV-2.

Structurally, there are more 20 proteins encoded by the genome of this virus, which comprises the $3 \mathrm{C}$-like protease $\left(3 C L^{\text {pro }}\right.$ or $\left.\mathrm{M}^{\text {pro }}\right)$, which shares a higher similarity with SARS-CoV than to MERS-CoV ${ }^{7-9}$. The $3 \mathrm{CL}^{\text {pro }}$ is a homodimer, comprising two protomers, and a catalytic dyad site constructed by Cys 145 and His41 residues, established among the domain I and II (Figure 1) ${ }^{10,11}$. The imperative of this enzyme has an important part in the transcription cycle and viral replication ${ }^{12-15}$. Therefore, its structure and the catalytic mechanism of this enzyme make it a selective drug target and computer-aided drug design $(C A D D)^{7,16}$. Since, the crystal structure of $3 C^{\text {pro }}$ of SARS-CoV-2, complexed with an inhibitor N3 has recently released ${ }^{17}$, there are various tremendous effort has been implementing various methods for therapeutic discovery against SARS-CoV-2 through virtual screening ${ }^{16,18-22}$. Majorly, these studies have been performed using three datasets of different compounds, i.e., Food and Drug Administration (FDA) approved drugs ${ }^{23,24}$, previous main protease inhibitors database ${ }^{25}$, and natural products ${ }^{5,26}$, on the $3 \mathrm{CL}^{\text {pro }}$ enzyme to recognise possible lead molecules. Considering the fast pace of SARS-CoV-2 pandemic travelled rapidly around the world, repurposing of antiviral small molecules derived from natural products are deliberated as an important therapeutic tactic for the treatment of this deadly virus, as they can be less toxic or minor side effects and cost effective 5,26-30. $^{\text {. }}$

Indonesia is one of a mega biodiversity country in the world, which has around 20,000 plant species, which are around 1,180 species have the prospective to be medicine plants. Jamu (a word in Javanese tribal language), is Indonesian traditional herbal medicine that has been established in the Indonesian society for many years in treating various diseases and maintaining good health ${ }^{31-34}$. Various pharmacological properties including antiviral properties related to the utilisation of Jamu have been reported ${ }^{32}$. Bearing in mind with the increasing risk of COVID-19 pandemic, it is highly desirable to seek for natural and safe medicines from Indonesian herbal medicinal plants used in Jamu against SARS- 
CoV-2. Therefore, we conducted molecular docking studies along with pharmacokinetics and DFT studies of some of the considered bioactive compounds from several medicinal plants used in Jamu against the $3 \mathrm{CL}^{\text {pro }}$ to identify the possible inhibitors of this viral diseases.

\section{Experimental}

\section{Preparation of ligands and protein for the study}

The 20 selected list medicinal plants used in Jamu and their 49 bioactive phytochemicals were collected from the previous literature ${ }^{32,35}$ as listed in Table S1. The 3D structures of the selected phytochemicals from Jamu were retrieved from the PubChem Open Chemistry Database (https://pubchem.ncbi.nlm.nih.gov/) and saved in SDF format. The crystallography structures of the $3 \mathrm{CL}^{\text {pro }}$ of SARS-CoV-2 was retrieved from the RCSB PDB database (www.rcsb.org) with PDB ID: 6LU7 (resolution: $2.16 \AA$ ). Afterwards, it was processed by removing the native ligand $\mathrm{N} 3$ and water molecules. Additionally, the missing hydrogen atoms were added to impart electric charge and magnetic field using Pymol Molecular Visualisation Software ${ }^{36}$. To identify the active sites of selected receptors, an online tool prediction PrankWeb (http://prankweb.cz/) was performed. Finally, before the docking studies were carried out, polar hydrogen atoms and Gasteiger charges were added.

\section{Molecular docking studies}

A virtual screening software PyRx ${ }^{37}$, which integrated with AutoDock Vina ${ }^{38}$ was used to perform molecular docking studies, with the feasible region centre $\mathrm{x}=$ -16.1444842361 , centre_y $=11.6003195758$, centre_z $=68.5165891098$, size_ $x=31.5482838191$ size_ $y=31.1936216545$ size $\_z=37.2738800873$ and exhaustiveness $=8$. The interactions between the ligands and our targeted proteins were visualised using the BIOVIA Discovery Studio 2020.

\section{Pharmacokinetics studies of bioactive phytochemicals}

The pharmacokinetics profiling of bioactive phytochemicals was determined based on Lipinski's rule of five using the online tools Molinspiration (https://www.molinspiration.com/cgi-bin/properties) and SwissADME (http://www.swissadme.ch/). They were further tested for in silico ADMET studies, i.e., absorption, distribution, metabolism, excretion, and toxicity using admetSAR (http://Immd.ecust.edu.cn/admetsar1). The canonical SMILEs of the selected bioactive phytochemicals molecular structures were obtained from the PubChem database (www.pubchem.ncbi.nlm.nih.gov).

\section{Molecular target prediction}

Bioactive small molecules derived from natural products can interact with the various number of protein-binding to proteins or other macro-molecular targets such as enzymes and lipids. Because of the importance of these interactions in unravelling the molecular mechanism of the ligands, identifying the molecular 
targets for new molecules is considered very crucial to study, which can be accessed using an accessible free of charge Swiss Target Prediction (http://www.swisstargetprediction.ch/index.php) ${ }^{39}$.

\section{Prediction of activity spectra for substances (PASS)}

To estimate the biological activity, particularly antiviral activities of the studied bioactive phytochemicals, an accessible free of charge a computer program PASS (http://www.way2drug.com/) was established ${ }^{40}$. Density-functional theory (DFT) studies

The DFT calculation for all the investigated bioactive phytochemicals was demonstrated through GAUSSIAN 09 suit of program, using 6-31G $(d, p)$ basis set with the Lee-Yang-Parr exchange-correlation (B3LYP) density functional in the gas phase. Through DFT calculation, it is possible to estimate the values of highest occupied molecular orbital (HOMO) and lowest unoccupied molecular orbital (LUMO), total energy, gap energies $\left(\Delta \mathrm{E}_{\text {gap }}\right)$. Furthermore, several global

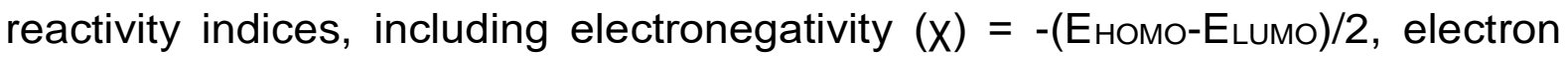
affinity $(A)=-$ ELUmo, ionisation energy $(I)=-E_{\text {Hомо }}$, chemical potential $(\mu)=1 / 2$ (Elumo + Eномо), chemical softness $(S)=1 / 2 \eta$, chemical hardness $(\eta)=1 / 2$ (E LUмо - Eномо) and electrophilicity index $(\omega)=\mu^{2} / 2 \eta$ were determined ${ }^{41,42}$. Additionally, to access the detail information of nucleophilic and electrophilic sites, a molecular electrostatic potential (MEP) calculation derived from Mulliken charge was performed.

\section{Result}

\section{Binding affinity studies}

The current epidemic of highly infectious diseases COVID-19 pandemics desires the immediate multiple plans of treatments as soon as possible. Recently, a new horizon about the study of SARS CoV-2 became quite interesting after Yang and co-workers solved the crystal structure of $3 \mathrm{CL}^{\text {pro }}$ of SARS-CoV-2 with N3 complex. Since the $3 \mathrm{CL}^{\text {pro }}$ known as the controls activities of the virus replication, it was highly considered as an attractive drug target and $\mathrm{CADD}^{10}$. Encouraged with this, we performed virtual screening based on molecular docking for the 49 bioactive phytochemicals from several medicinal plants used in Jamu by using AutoDock Vina to know their binding mode with 3CLpro.

Through a molecular docking study, the structural conformations between active sites of small molecule drug candidates to ligand targets are possible to predicted $^{14}$. It was observed that the 49 bioactive phytochemicals have binding energy to $3 \mathrm{CL}^{\text {pro }}$ which ranges from -4.2 to $-8.5 \mathrm{Kcal} / \mathrm{mol}$, as summarised in Table S2. Whereas, the interaction of the 11 bioactive phytochemicals with best binding affinities and N3 as reference inhibitor against $3 \mathrm{CL}^{\text {pro }}$ enzyme is presented in Table 1. Out of the 7 compounds, Procyanidins was found to have the highest docking score $(-8.5 \mathrm{Kcal} / \mathrm{mol})$. It was observed that the binding 
affinity of Procyanidins $(-8.9 \mathrm{Kcal} / \mathrm{mol})$, Naringin $(-8.3 \mathrm{Kcal} / \mathrm{mol})$, Hesperidin ($8.1 \mathrm{Kcal} / \mathrm{mol})$, Aloin A $(-8.0 \mathrm{Kcal} / \mathrm{mol})$, Apigenin $(-7.8)$, Kaempferol $(-7.8$ $\mathrm{Kcal} / \mathrm{mol})$, Naringenin $(7.7 \mathrm{Kcal} / \mathrm{mol})$ and Catechin $(-7.5 \mathrm{Kcal} / \mathrm{mol})$ surpassed that of the reference inhibitor N3 $(-7.5 \mathrm{Kcal} / \mathrm{mol})$. Whereas, Luteolin $(-7.4$ $\mathrm{Kcal} / \mathrm{mol})$, Taxifolin $(-7.4 \mathrm{Kcal} / \mathrm{mol})$, and Curcumin $(-7.2 \mathrm{Kcal} / \mathrm{mol})$ were observed had a binding affinity lower than the reference. Amongst, it is important to note that the 6 bioactive phytochemicals (Apigenin, Catechin, Luteolin, Naringenin, Procyanidins, and Taxifolin) are obtained from one species Tamarindus indica, while three bioactive compounds (Naringin, Naringenin, and Hesperidin) are obtained from Citrus aurantifolia. Notably, Naringenin also can be obtained from either in Tamarindus indica or Citrus aurantifolia. Aloin A, Curcumin, and Kaempferol can be obtained from Aloe vera, Curcuma domestica, and Foeniculum vulgare, respectively.

\section{Pharmacokinetics studies of bioactive phytochemicals}

All the 11 top-ranked bioactive phytochemicals along with positive control N3 were determined for their pharmacokinetic properties (Table S3). The druglikeness concept can qualitatively determine the oral bioavailability of a compound. Particularly, it is selected to optimise pharmacokinetics, pharmacodynamics, and pharmaceutical properties of drugs, such as the solubility, bioavailability, chemical stability, and distribution profile in the human body ${ }^{43,44}$. An orally bioactive drug is projected not to violate more than one of the criteria for drug-likeness, i.e., molecular weight $(\mathrm{MW}) \leq 500$, partition coefficient (cLogP) $\leq 5$, number of hydrogen bond donors (HBD) $\leq 5$, and number of hydrogen acceptors (HBA) $\leq 10^{45}$.

Notably, from a total of 11 bioactive phytochemicals, 7 compounds, i.e., Apigenin, Kaempferol, Naringenin, Catechin, Luteolin, Taxifolin, and Curcumin were found to be orally bioactive concerning the criteria of Lipinski's Rule of Five in combination with lipophilicity, MW, polarity, solubility, saturation, flexibility in satisfactory range as shown in radar plots (Table S3, Figure 2). Aloin A suffered from in the number HBD $>5$ while Hesperidin, Naringin, and Procyanidins were majorly obeyed Lipinski's Rule of Five by their MW (>500 g/mol), HBD (>5), and number of HBA $(>10)$. On comparing with the N3 as a native inhibitor of $3 \mathrm{CL}^{\text {pro, }}$, this compound was found to be a non-orally available drug, which obeyed Lipinski's Rule of Five, i.e., the MW ( $>500 \mathrm{~g} / \mathrm{mol})$. Notably, all of the 7 bioactive phytochemicals are water-soluble and also characterised by high gastrointestinal (Gl) absorption value. The water solubility value of a drug is an essential factor in the drug discovery due to associated with its absorption, formulation, and administration pathway of a drug. Besides, it should be noted that the high value of $\mathrm{Gl}$ absorption would be beneficial for rapid tissue distribution to reach the pulmonary tissue. Indeed, currently used drugs i.e., Chloroquine, Lopinavir, and Camosta are characterised by their high Gl absorption ${ }^{46}$. As expected, all of the 7 bioactive phytochemicals showed a bioavailability score of $55 \%$, which indicates good bioavailability. Furthermore, 
all the seven filtered bioactive phytochemicals displayed negative AMES toxicity advised that these 7 bioactive phytochemicals are non-carcinogenic. Furthermore, this result was also supported by the oral rat acute toxicity (LD50). Altogether, this precious information showed that these 7 bioactive phytochemicals can be safely used as drugs. Based on the favourable physicochemical properties exhibited, these bioactive phytochemicals were selected for further studies.

\section{Identification of target class for the eleven bioactive phytochemicals via target prediction studies}

Computational predictions play an imperative key in limiting the pool of potential targets and proposing secondary targets for known molecules ${ }^{39,47}$. Therefore, we performed molecular target studies, which is an essential key to find the potential phenotypes, cross-reactivity or predicting potential side effects and optimizing produced by the action of the 7 best bioactive phytochemicals ${ }^{39}$. The structural motif of the 7 best ligands permits them to serve as outstanding HBD, which helped them to bind with several biomacromolecules, e.g. enzyme or proteins. The formed interaction is considered to be a crucial phase in the controlling role of the 7 bioactive phytochemicals on numerous main proteins elaborate in cellular physiology. In the current context, this study is principally crucial as we think that the 7 best ligands could target $3 C^{\text {pro }}$ of SARS-CoV-2, an essential enzyme that catalysed the RNA replication. Figure 3 shows the top 25 of the targets predicted for the top bioactive phytochemicals from several medicinal plants used in Jamu and control (N3). Remarkably, all the 7 bioactive phytochemicals have outstanding properties of drug ability, which are could interact with a various class of enzymes or proteins.

\section{Comparative binding affinity and ligand-protein interaction analysis of the lead molecules with N3 binding site in 3CL pro of SARS-CoV-2}

Once we identified that these 7 bioactive phytochemicals are non-toxic, we studied their ligand-protein interaction against $3 \mathrm{CL}^{\text {pro }}$ enzyme. Dominantly, all of these 7 bioactive phytochemicals interacted with the residues of $3 \mathrm{CL}^{\text {pro }}$ via hydrophobic interactions and with a few HBs, as presented in Table 2. The N3 complex yields the binding energy of $-7.5 \mathrm{Kcal} / \mathrm{mol}$, which was relatively equal to the previously reported estimation ${ }^{19,48,49}$. According to previous reports, the N3 complex analysis advised that this inhibitor is stabilised by variable several hydrophobic and HB interactions, in particular with the catalytic dyad. As reported, the catalytic dyad has been recognised as the controller of the catalytic activity of $3 C L^{\text {pro }}$ enzyme ${ }^{17,50,51}$. Therefore, we can conclude that the binding of the inhibitor N3 to both residues of catalytic dyad may be a pivotal factor. Our study showed that the molecular interaction between N3 and $3 \mathrm{CL}^{\text {pro }}$ was facilitated through three HBs with residues Gly143, Cys145 and His164 along with various hydrophobic interactions as presented in Figure 4.

The binding poses of the protein-ligand interaction study revealed that all ligands had excellent binding stability, occupying the active site in varying ways 
at the N3 binding site of $3 \mathrm{CL}^{\text {pro, }}$, as presented in Figure 4. Remarkably, they have also interacted with the catalytic dyad of $3 \mathrm{CL}^{\text {pro }}$ via $\mathrm{HB}$ and/or hydrophobic interactions only. This is suggesting that the top 7 bioactive compounds derived from medicinal plants used in Jamu may serve as a potential inhibitor candidate against $3 \mathrm{CL}^{\text {pro }}$ of SARS-CoV-2. Accordingly, Luteolin and Naringenin were the two bioactive compounds that only interacted to one of the catalytic dyads of $3 \mathrm{CL}^{\text {pro }}$ (Cys145) through a conventional HB. Additionally, both of these complexes were also stabilised through van der Waals interaction to the other of the catalytic dyad (His41). Whereas, no HB interaction with a catalytic dyad of $3 \mathrm{CL}^{\text {pro }}$ was observed in the complex of Apigenin, Catechin, Curcumin, Kaempferol, and Taxifolin. Therefore, for further study, we have shortlisted two leads molecules, i.e., on Luteolin and Naringenin, in which Luteolin can be obtained only from Tamarindus indica while Naringenin can be obtained from Tamarindus indica and Citrus aurantifolia. Furthermore, it was noticed that the HB of Cys 145 residue strengthens by the establishment of pi-alky interaction. Furthermore, it also interacted with several important residues required for the substrate-binding pocket designated as S1 (Gly143, Cys145, and Glu166), S2 (His41and Cys145), S3 (His41, Met49, and Met165), S4 (Met165 and Glu166), and S5 (Met165, Glu166, and Gln189) $8,17,51$.

The second lead molecule, i.e., Naringenin, with a considerably higher energy binding $(-7.7 \mathrm{Kcal} / \mathrm{mol})$ than Luteolin $(-7.4 \mathrm{Kcal} / \mathrm{mol})$ also showed significant binding with $3 \mathrm{CL}^{\text {pro. }}$. It stabilised via three HBs with residues Cys145, Glu166, and Asp187, van der Waals interaction with residues His41, Pro54, Tyr54, Leu141, Asn142, Ser144, His164, Met165, Arg188, Gln189, unfavourable donor-donor interaction with residue Gly143, Cation-m interaction with residue His163, and pi-alkyl interaction with Met49, as displayed in Figure 5, Table 2. Naringenin interacted with the catalytic dyad of $3 \mathrm{CL}^{\text {pro }}$ through HBs (Cys145) and hydrophobic interaction (His41). It was also noticed that the catalytic dyad residue Cys 145 stabilised via $\mathrm{HB}$ and pi-alkyl interaction. Luteolin also exhibited interaction with S1 (Gly143, Cys145, His163, and Glu166), S2 (His41 and Cys145), S3 (His41, Met49, and Met165), S4 (Met165 and Glu166), and S5 (Met165, Glu166 and Gln189) 8,17,51. From this result, it is clear that both bioactive phytochemicals, Luteolin and Naringenin have interactions with the active site and substrate-binding pocket located between the clefts of domain I and II of the $3 \mathrm{CL}^{\text {pro }}$. Altogether, because of Luteolin and Naringenin showed good binding energies and interactions along with the highly conserved as a substrate-recognition pocket of the SARS-CoV-2 concerning the N3 inhibitor, it is suggested that these compounds can be hired for the development of antiviral drugs against SARS-CoV-2.

\section{Prediction of activity spectra for substances (PASS)}

Further, using PASS software ${ }^{40}$, we investigated the biological activity spectra of the Luteolin and Naringenin. Table 3 shows a portion of the envisaged biological activity particularly antiviral activities for Luteolin and Naringenin with 
N3. The result of the PASS analysis is presented as the list of antiviral activities along with suitable $\mathrm{Pa}$ and $\mathrm{Pi}$ ratio. These values will estimate the possibility for the investigated compound to be active and inactive. From the result, it showed that both Luteolin and Naringenin revealed various antiviral properties such as N3, which means that these compounds could be suggested as an antiviral agent.

\section{DFT studies}

DFT is one of the most well-established methods to determine the correlation between experimental result and the molecular structure, which offers various important data on the structure and reactivity of molecular perspective ${ }^{52,53}$. HOMO and LUMO belong to Frontier molecular orbitals (FMOs), which control the mode of the interaction between a molecule with other species. This concept can provide realistic qualitative data about the susceptibility of the electrons transfer from the HOMO to the LUMO orbital. Figure 6 showed the graphic results from DFT calculations. The FMOs energy analysis, as presented in Table 4, showed that Luteolin has the most lying HOMO energy compared to Naringenin and N3, indicating it can be a better electron donor as a drug. Meanwhile, the LUMO energy of Naringenin is found to be higher than the others. Accordingly, Energy gap ( $\Delta \mathrm{E}_{\text {gap }}$ ) value of the investigated molecules is in the order of Luteolin $<\mathrm{N} 3<$ Naringenin.

Further, through DFT calculation, the global reactivity indices, such as $\eta S, \chi, \mu$ and $\omega$, which are essential to describe the reactivity and stability of the studies compounds, where also can be determined, as presented in Table 4. It was observed that Naringenin characterised by the highest value of $\eta$ compared to N3 and Luteolin, indicating it should be the lowest in reactivity (more stable species) compared to the other studied molecules. The high value of $S, X, \mu$ and $\omega$ signify the reactivity for Naringenin, which agreeably relates with the molecular docking finding.

To provide identification and prediction about reactive sites for nucleophilic and electrophilic attacks of the investigated compounds, MEP map was established, as depicted in Figure 6. Both of Luteolin and Naringenin, the negative electrostatic potential regions (red) mostly centred over the hydroxyl (O5) and carbonyl (O4) functional groups, while the negative electrostatic potential regions of N3 mostly focused over the oxygen atoms of carbonyl groups while the positive values are centred over the $\mathrm{N}$ atoms. These features could be used for further explanation about the biological recognition and $\mathrm{HB}$ or van der Walls interactions with protein receptors ${ }^{54}$. Generally, this result is found to be following with the molecular docking result. As presented in Figure 5, it is obvious, that the hydroxyl (O5) and carbonyl (O4) revealed the formation of $\mathrm{HB}$ or van der Walls interactions with $3 \mathrm{CL}^{\text {pro }}$ of SARSCoV-2.

\section{Discussion}

The outbreak of highly infectious SARS-CoV-2 requires identification of various treatment strategies as soon as possible. In this current pandemic situation, time 
is crucial. An effort to discover new drugs commonly needs a long time and expense. Therefore, the quick discovery leads antiviral compounds from natural sources known such as several herbal medicines used in Jamu ${ }^{32,35}$, would be a good alternative to treat SARS-CoV-2 due to their high safety and applicability ${ }^{29}$. In fact, according to the record of the World Health Organization (WHO), 80\% of the global population worldwide depends on traditional plants for health needs, particularly in developing countries ${ }^{55}$. The utilisation of herbal medicinal plants is a prominent resource for novel antiviral drug discovery and development ${ }^{28,56}$. Therefore, gaining the benefit of the newly released $3 \mathrm{CL}^{\text {pro }}$ of SARS CoV-2 crystal structure ${ }^{17}$, we performed virtual docking screening of bioactive phytochemicals from several medicinal plants used in Jamu in an attempt to find novel hit molecules to combat this deadly virus.

According to the obtained result of pharmacokinetic and PASS studies, Luteolin and Naringenin were considered for further studies. Luteolin and Naringenin revealed that both these compounds followed the Lipinski rule of five for high drug ability with no violation. They also showed low Gl absorption and the high volume of distribution, therefore, if given orally, they should attain therapeutic effects upon oral administration. On the other hand, compounds such as N3, Aloin A, Hesperidin, Naringin, and Procyanidins should be given via intravenous injection due to their low Gl absorption and low volume of distribution. The high-water solubility in Luteolin and Naringenin can be due to the presence of 3 hydroxyl groups in Luteolin and 4 hydroxyl groups in Naringenin, which are capable of forming bonds with water molecules ${ }^{57}$. Additionally, toxicity profiling depicted, Luteolin and Naringenin are noncarcinogenic. This result further demonstrated the drugability potential of these two flavonoid compounds, which may serve as a valuable hint to a structurebased design of drugs that targets the main protease of SARS-CoV-2.

Structurally, Luteolin and Naringenin are belonging to a member of flavonoids, a heterogeneous polyphenolic compound that can be found in many plants. Flavonoids are a natural product which plays an essential key in plant physiology and they were explored for having various advantageous bioactivity to health, such as anticancer, antimicrobial, anti-lipogenic, antioxidant, antiinflammatory, and antiviral properties ${ }^{57,58}$. A recent study advises that several types of flavonoid such as apigenin, quercetin, kaempferol, naringenin, and luteolin are the most suggested compounds that may act as the potential

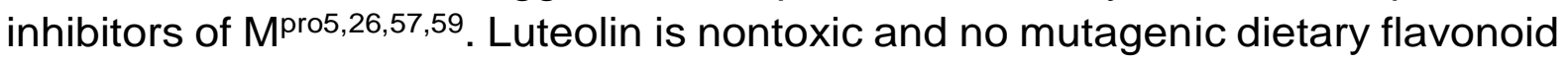
(polyphenolic plant secondary metabolites), which reported possesses various pharmacological uses such as antioxidant, anticancer, anti-inflammatory, and antiviral60,61. Apart from the Tamarindus indica plant, it can also be found in various plants such as green pepper, camomile tea, and celery, perilla leaf in nature ${ }^{62}$. Remarkably, it has been well-documented that Luteolin can be used as an antiviral agent against various viral diseases such as HIV, HBV, and EV71 via various mechanisms. ${ }^{61,63,64}$. Whereas, Naringenin is one the most important 
flavanones in the aglycone form, which possess an inhibition on the CHIKV replicon cell system, hepatitis C virus (HCV), HIV-1 virus, and yellow fever virus $^{65-68}$. The previous study also observed that Naringenin can be identical to nelfinavir, a protease inhibitor used in to treat the HIV diseases ${ }^{69}$.

Luteolin and Naringenin were found to have interacted with the $3 \mathrm{CL}^{\text {pro }}$ with a binding free energy of -7.4 and $-7.8 \mathrm{Kcal} / \mathrm{mol}$, respectively. The good binding affinity value of Luteolin and Naringenin complexes can be attributed to their chemical structure which has the aromatic ring systems as shown by N3, therefore presenting closer or higher binding free energy value. The aromatic rings system from these two polyphenolic compounds produce various hydrophobic interactions such as $\pi-$ alkyl and $\pi-\pi$ interactions with the residues of the $3 \mathrm{CL}^{\text {pro }}$ enzyme, thus they can stabilise the formed complexes. Additionally, the presence of hydroxyl groups also considered being an important contributor for stabilising the formed complexes, particularly to form $\mathrm{HB}$ with enzyme residues. The monomer of $3 \mathrm{CL}^{\text {pro }}$ has comprised of three domains (Figure 4). An important catalytic dyad of $3 \mathrm{CL}^{\text {pro }}$ occupies in the gap between the domains I and $\mathrm{II}^{70}$. In particular, Luteolin and Naringenin could

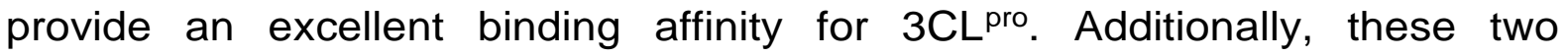
complexes were able to interact with their essential catalytic dyad residues (Cys145 and His44) of $3 \mathrm{CL}^{\text {pro70}}$. Extraordinarily, Luteolin and Naringenin also interacted with Asp187 residue that is known to improve the catalytic efficiency of $3 \mathrm{CLpro}^{71}$. These results strengthen that these two bioactive phytochemicals from several medicinal plants used in Jamu have the prospect to be used as inhibitors of $3 \mathrm{CL}^{\text {pro. }}$.

Figure 7 presented the frequency distribution of non-covalent interactions of

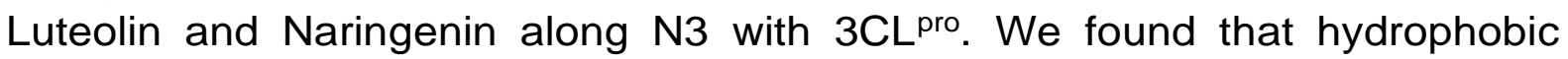
interactions were most frequently observed in these protein-ligand complexes. Previously, it is already known that the main driving force in drug-receptor interactions is occupied by hydrophobic interactions ${ }^{72}$. Hydrophobic interactions between Luteolin, Naringenin, and N3 with $3 \mathrm{CL}^{\text {pro }}$ have appeared in several types such as van der Waals, alkyl, and pi-alkyl interaction. The densest clusters are those formed by aromatic carbon in ligands and aliphatic carbon in receptors. It is interesting to notice that the existences of aromatic rings are an important key in the inhibition of small molecules.

Interestingly, the aromatic ring system, with benzene being the most common ring system against about $76 \%$ of the approved drugs ${ }^{73,74}$. Thus, not surprisingly, Luteolin, Naringenin, and N3 side-chains are frequently involved in hydrophobic interactions. After that, we found that HB was the second most frequently observed interaction. Luteolin and N3 have formed $4 \mathrm{HBs}$ with protein while Naringenin was formed 3 HBs. In biological complexes, HBs are influential directional intermolecular interactions and play a major role in the specificity of molecular recognition ${ }^{75,76}$. Out of 3 studied molecules, only N3 showed weak $\mathrm{HB}$ interactions (that $\mathrm{C}-\mathrm{H} \cdots \mathrm{O}$ ). It has recognised that this 
interaction shows an imperative part in the stabilisation of protein-ligand binding complexes ${ }^{77,78}$. Lastly, the cation- $\pi$ interaction is observed only in the Naringenin complex, which is formed by a negatively charged electron cloud of the Naringenin $\pi$ system. This interaction is also recognised to be an important interaction because of its ability to determine the structure, stability, and function of proteins ${ }^{79}$.

Finally, by comparing the results of molecular docking, pharmacokinetic, and DFT studies of the investigated compounds, Luteolin, and Naringenin may be considered as potential main protease inhibitors of SARS-CoV-2. Concerning this result, we proposed the plausible mechanism of Luteolin and Naringenin in combating of SARSCoV-2, as depicted in Figure 8. The virus will release its genomic RNA upon entry into the targeted host cells. After that, a translation process will be carried out to produce polyproteins, which are cleaved into the main protease $3 \mathrm{CL}^{\text {pro }}$ and a non-structural protein (nsps). In this process, the $3 \mathrm{CL}^{\text {pro }}$ is elaborate in the yielding of nsps, which is very crucial for assembling the viral replication transcription complex (RTC) to take a part in the synthesis of RNA ${ }^{80}$. When inhibitors, such as Luteolin and Naringenin administrated into the cellular system, they will bind and inhibit the activity of $3 \mathrm{CL}^{\text {pro. }}$. In the end, the targeted host cell will fail to yield the new intact virions.

\section{Conclusions}

Keeping in mind that $3 \mathrm{CL}^{\text {pro }}$ of SARS-CoV-2 inhibitors play an essential key to fight the COVID-19 pandemic, we have demonstrated the molecular docking studies of some of the considered bioactive compounds from several medicinal plants used in Jamu against the $3 \mathrm{CL}^{\text {pro }}$. Our findings propose that Luteolin and Naringenin had excellent binding stability with $3 \mathrm{CL}^{\text {pro }}$ enzyme, which was found to be very consistent with main protease inhibitors and possible to be orally drug candidates. Both these compounds interacted with the Cys 145 residue from catalytic dyad of $3 \mathrm{CL}^{\text {pro }}$ through $\mathrm{HBs}$ along with their hydrophobic interactions with His41 residue. Altogether, along with pharmacokinetic and DFT studies, our findings reveal that Tamarindus indica (Luteolin and Naringenin) and Citrus aurantifolia flavonoids (Naringenin) can be natural sources of potent antiCOVID-19 drug candidates. Furthermore, experiments studies should be needed to confirm the feasible preclinical and clinical efficacy of these potential antiviral small-molecules to inhibit the $3 \mathrm{CL}^{\text {pro }}$ enzyme of this viral disease.

\section{Conflicts of interest}

There are no conflicts to declare.

\section{Ethical Declaration}

As it is an in-silico study, there were no experiments on animals or human involvement. 


\section{Notes and references}

(1) Lai, C. C.; Shih, T. P.; Ko, W. C.; Tang, H. J.; Hsueh, P. R. Severe Acute Respiratory Syndrome Coronavirus 2 (SARS-CoV-2) and Coronavirus Disease-2019 (COVID-19): The Epidemic and the Challenges. Int. J. Antimicrob. Agents 2020, 55 (3), 105924. https://doi.org/10.1016/j.ijantimicag.2020.105924.

(2) Kaul, D. An Overview of Coronaviruses Including the SARS-2 Coronavirus Molecular Biology, Epidemiology and Clinical Implications. Curr. Med. Res. Pract. 2020, 10 (2), 54-64. https://doi.org/10.1016/j.cmrp.2020.04.001.

(3) Hui, D. S.; I Azhar, E.; Madani, T. A.; Ntoumi, F.; Kock, R.; Dar, O.; Ippolito, G.; Mchugh, T. D.; Memish, Z. A.; Drosten, C.; Zumla, A.; Petersen, E. The Continuing 2019-NCoV Epidemic Threat of Novel Coronaviruses to Global Health - The Latest 2019 Novel Coronavirus Outbreak in Wuhan, China. Int. J. Infect. Dis. 2020, 91, 264-266. https://doi.org/10.1016/j.ijid.2020.01.009.

(4) Huang, F.; Li, Y.; Leung, E. L. H.; Liu, X.; Liu, K.; Wang, Q.; Lan, Y.; Li, X.; Yu, H.; Cui, L.; Luo, H.; Luo, L. A Review of Therapeutic Agents and Chinese Herbal Medicines against SARS-COV-2 (COVID-19). Pharmacol. Res. 2020, 158 (May), 104929. https://doi.org/10.1016/j.phrs.2020.104929.

(5) Allam, A. E.; Assaf, H. K.; Hassan, H. A.; Shimizu, K.; Elshaier, Y. A. M. M. An in Silico Perception for Newly Isolated Flavonoids from Peach Fruit as Privileged Avenue for a Countermeasure Outbreak of COVID-19 . RSC Adv. 2020, 10 (50), 29983-29998. https://doi.org/10.1039/d0ra05265e.

(6) Sonja A. Rasmussen, MD, MS, J. C. S. Since January 2020 Elsevier Has Created a COVID-19 Resource Centre with Free Information in English and Mandarin on the Novel Coronavirus COVID-. Ann Oncol 2020, No. January, 19-21. https://doi.org/10.1007/s00134-020-05991-x.Bizzarro.

(7) Ngo, S. T.; Quynh Anh Pham, N.; Thi Le, L.; Pham, D.-H.; Vu, V. V. Computational Determination of Potential Inhibitors of SARS-CoV-2 Main Protease. J. Chem. Inf. Model. 2020, acs.jcim.0c00491. https://doi.org/10.1021/acs.jcim.0c00491.

(8) Gahlawat, A.; Kumar, N.; Kumar, R.; Sandhu, H.; Singh, I. P.; Singh, S.; Sjöstedt, A.; Garg, P. Structure-Based Virtual Screening to Discover Potential Lead Molecules for the SARS-CoV-2 Main Protease. J. Chem. Inf. Model. 2020. https://doi.org/10.1021/acs.jcim.0c00546.

(9) He, J.; Hu, L.; Huang, X.; Wang, C.; Zhang, Z.; Wang, Y.; Zhang, D.; Ye, W. Potential of Coronavirus 3C-like Protease Inhibitors for the Development of New Anti-SARS-CoV-2 Drugs: Insights from Structures of Protease and Inhibitors. Int. J. Antimicrob. Agents 2020, 56 (2), 106055. https://doi.org/10.1016/j.ijantimicag.2020.106055.

(10) Anand, K.; Ziebuhr, J.; Wadhwani, P.; Mesters, J. R.; Hilgenfeld, R. Coronavirus Main Proteinase (3CLpro) Structure: Basis for Design of AntiSARS Drugs. Science (80-. ). 2003, 300 (5626), 1763-1767. https://doi.org/10.1126/science.1085658. 
(11) Anand, K.; Palm, G. J.; Mesters, J. R.; Siddell, S. G.; Ziebuhr, J.; Hilgenfeld, R. Structure of Coronavirus Main Proteinase Reveals Combination of a Chymotrypsin Fold with an Extra a-Helical Domain. EMBO J. 2002, 21 (13), 3213-3224. https://doi.org/10.1093/emboj/cdf327.

(12) Wu, C.; Liu, Y.; Yang, Y.; Zhang, P.; Zhong, W.; Wang, Y.; Wang, Q.; Xu, Y.; Li, M.; Li, X.; Zheng, M.; Chen, L.; Li, H. Analysis of Therapeutic Targets for SARS-CoV-2 and Discovery of Potential Drugs by Computational Methods. Acta Pharm. Sin. B 2020, 10 (5), 766-788. https://doi.org/10.1016/j.apsb.2020.02.008.

(13) De Wit, E.; Van Doremalen, N.; Falzarano, D.; Munster, V. J. SARS and MERS: Recent Insights into Emerging Coronaviruses. Nat. Rev. Microbiol. 2016, 14 (8), 523-534. https://doi.org/10.1038/nrmicro.2016.81.

(14) Chandel, V.; Raj, S.; Rathi, B.; Kumar, D. In Silico Identification of Potent Fda Approved Drugs against Coronavirus Covid-19 Main Protease: A Drug Repurposing Approach. Chem. Biol. Lett. 2020, 7 (3), 166-175.

(15) Li, Q.; Kang, C. B. Progress in Developing Inhibitors of Sars-Cov-2 3c-like Protease. Microorganisms 2020, 8 (8), 1-18. https://doi.org/10.3390/microorganisms8081250.

(16) Wang, J. Fast Identification of Possible Drug Treatment of Coronavirus Disease-19 (COVID-19) through Computational Drug Repurposing Study. J. Chem. Inf. Model. 2020, 60 (6), 3277-3286. https://doi.org/10.1021/acs.jcim.0c00179.

(17) Jin, Z.; Du, X.; Xu, Y.; Deng, Y.; Liu, M.; Zhao, Y.; Zhang, B.; Li, X.; Zhang, L.; Peng, C.; Duan, Y.; Yu, J.; Wang, L.; Yang, K.; Liu, F.; Jiang, R.; Yang, X.; You, T.; Liu, X.; Yang, X.; Bai, F.; Liu, H.; Liu, X.; Guddat, L. W.; Xu, W.; Xiao, G.; Qin, C.; Shi, Z.; Jiang, H.; Rao, Z.; Yang, H. Structure of Mpro from SARSCoV-2 and Discovery of Its Inhibitors. Nature 2020, 582 (7811), 289-293. https://doi.org/10.1038/s41586-020-2223-y.

(18) Bhowmik, D.; Nandi, R.; Jagadeesan, R.; Kumar, N.; Prakash, A.; Kumar, D. Identification of Potential Inhibitors against SARS-CoV-2 by Targeting Proteins Responsible for Envelope Formation and Virion Assembly Using Docking Based Virtual Screening, and Pharmacokinetics Approaches. Infect. Genet. Evol. 2020, 84 (June), 104451. https://doi.org/10.1016/j.meegid.2020.104451.

(19) Bharadwaj, S.; Lee, K. E.; Dwivedi, V. D.; Kang, S. G. Computational Insights into Tetracyclines as Inhibitors against SARS-CoV-2 Mpro via Combinatorial Molecular Simulation Calculations. Life Sci. 2020, 257 (July), 118080. https://doi.org/10.1016/j.Ifs.2020.118080.

(20) Sang, P.; Tian, S. H.; Meng, Z. H.; Yang, L. Q. Anti-HIV Drug Repurposing against SARS-CoV-2. RSC Adv. 2020, 10 (27), 15775-15783. https://doi.org/10.1039/d0ra01899f.

(21) Gurung, A. B.; Ali, M. A.; Lee, J.; Farah, M. A.; Al-Anazi, K. M. Unravelling Lead Antiviral Phytochemicals for the Inhibition of SARS-CoV-2 Mpro Enzyme through in Silico Approach. Life Sci. 2020, 255 (March), 117831. 
https://doi.org/10.1016/j.lfs.2020.117831.

(22) Kumar, S.; Sharma, P. P.; Shankar, U.; Kumar, D.; Joshi, S. K.; Pena, L.; Durvasula, R.; Kumar, A.; Kempaiah, P.; Poonam; Rathi, B. Discovery of New Hydroxyethylamine Analogs against $3 \mathrm{CL}$ pro Protein Target of SARS-CoV-2: Molecular Docking, Molecular Dynamics Simulation, and Structure-Activity Relationship Studies. J. Chem. Inf. Model. 2020, xxx (xxx), xxx-xxx. https://doi.org/10.1021/acs.jcim.0c00326.

(23) De Wilde, A. H.; Jochmans, D.; Posthuma, C. C.; Zevenhoven-Dobbe, J. C.; Van Nieuwkoop, S.; Bestebroer, T. M.; Van Den Hoogen, B. G.; Neyts, J.; Snijder, E. J. Screening of an FDA-Approved Compound Library Identifies Four Small-Molecule Inhibitors of Middle East Respiratory Syndrome Coronavirus Replication in Cell Culture. Antimicrob. Agents Chemother. 2014, 58 (8), 4875-4884. https://doi.org/10.1128/AAC.03011-14.

(24) Dyall, J.; Coleman, C. M.; Hart, B. J.; Venkataraman, T.; Holbrook, M. R.; Kindrachuk, J.; Johnson, R. F.; Olinger, G. G.; Jahrling, P. B.; Laidlaw, M.; Johansen, L. M.; Lear-Rooney, C. M.; Glass, P. J.; Hensley, L. E.; Frieman, M. B. Repurposing of Clinically Developed Drugs for Treatment of Middle East Respiratory Syndrome Coronavirus Infection. Antimicrob. Agents Chemother. 2014, 58 (8), 4885-4893. https://doi.org/10.1128/AAC.03036-14.

(25) Chan, J. F. W.; Chan, K. H.; Kao, R. Y. T.; To, K. K. W.; Zheng, B. J.; Li, C. P. Y.; Li, P. T. W.; Dai, J.; Mok, F. K. Y.; Chen, H.; Hayden, F. G.; Yuen, K. Y. Broad-Spectrum Antivirals for the Emerging Middle East Respiratory

Syndrome Coronavirus. J. Infect. 2013, 67 (6), 606-616. https://doi.org/10.1016/j.jinf.2013.09.029.

(26) Sayed, A. M.; Khattab, A. R.; AboulMagd, A. M.; Hassan, H. M.; Rateb, M. E.; Zaid, H.; Abdelmohsen, U. R. Nature as a Treasure Trove of Potential AntiSARS-CoV Drug Leads: A Structural/Mechanistic Rationale. RSC Adv. 2020, 10 (34), 19790-19802. https://doi.org/10.1039/D0RA04199H.

(27) Enmozhi, S. K.; Raja, K.; Sebastine, I.; Joseph, J. Andrographolide as a Potential Inhibitor of SARS-CoV-2 Main Protease: An in Silico Approach. $J$. Biomol. Struct. Dyn. 2020, 0 (0), 1-7. https://doi.org/10.1080/07391102.2020.1760136.

(28) Mpiana, P. T.; Ngbolua, K. te N.; Tshibangu, D. S. T.; Kilembe, J. T.; Gbolo, B. Z.; Mwanangombo, D. T.; Inkoto, C. L.; Lengbiye, E. M.; Mbadiko, C. M.; Matondo, A.; Bongo, G. N.; Tshilanda, D. D. Identification of Potential Inhibitors of SARS-CoV-2 Main Protease from Aloe Vera Compounds: A Molecular Docking Study. Chem. Phys. Lett. 2020, 754 (June), 137751. https://doi.org/10.1016/j.cplett.2020.137751.

(29) Narkhede, R. R.; Pise, A. V.; Cheke, R. S.; Shinde, S. D. Recognition of Natural Products as Potential Inhibitors of COVID-19 Main Protease (Mpro): In-Silico Evidences. Nat. Products Bioprospect. 2020, No. 0123456789. https://doi.org/10.1007/s13659-020-00253-1.

(30) Owis, A. I.; El-Hawary, M. S.; El Amir, D.; Aly, O. M.; Abdelmohsen, U. R.; 
Kamel, M. S. Molecular Docking Reveals the Potential OfSalvadora Persicaflavonoids to Inhibit COVID-19 Virus Main Protease. RSC Adv. 2020, 10 (33), 19570-19575. https://doi.org/10.1039/d0ra03582c.

(31) Torri, M. Knowledge and Risk Perceptions of Traditional Jamu Medicine among Urban Consumers. European J. Med. Plants 2013, 3 (1), 25-39. https://doi.org/10.9734/ejmp/2013/1813.

(32) Elfahmi; Woerdenbag, H. J.; Kayser, O. Jamu: Indonesian Traditional Herbal Medicine towards Rational Phytopharmacological Use. J. Herb. Med. 2014, 4 (2), 51-73. https://doi.org/10.1016/j.hermed.2014.01.002.

(33) Sumitro, S. B. Computational Docking Study of Multitarget Bioactive Compounds in Indonesia Traditional Herbal Medicine for Tuberculosis Therapy. Int. J. GREEN Pharm. 2018, 12 (04), 258-260. https://doi.org/10.22377/ijgp.v12i04.2202.

(34) Hartanti, D.; Dhiani, B. A.; Charisma, S. L.; Wahyuningrum, R. The Potential Roles of Jamu for COVID-19: A Learn from the Traditional Chinese Medicine. Pharm. Sci. Res. 2020, 7 (4), 12-22. https://doi.org/10.7454/psr.v7i4.1083.

(35) Husain, F.; Wahidah, B.; Prasetyo, K.; Massholeh, M. Traditional Knowledge of Medicinal Plants among Sellers of Jamu Gendong in Wonolopo, Indonesia. In Proceedings of the First International Conference on Advances in Education, Humanities, and Language, ICEL 2019, Malang, Indonesia, 23-24 March 2019; EAl, 2019. https://doi.org/10.4108/eai.23-3-2019.2284999.

(36) Lill, M. A.; Danielson, M. L. Computer-Aided Drug Design Platform Using PyMOL. J. Comput. Aided. Mol. Des. 2011, 25 (1), 13-19. https://doi.org/10.1007/s10822-010-9395-8.

(37) Dallakyan, S.; Olson, A. J. Small-Molecule Library Screening by Docking with PyRx. In Global Food Security Governance; 2015; Vol. 1263, pp 243-250. https://doi.org/10.1007/978-1-4939-2269-7_19.

(38) Trott,O., Olson, A. J. Autodock Vina: Improving the Speed and Accuracy of Docking. J. Comput. Chem. 2019, 31 (2), 455-461. https://doi.org/10.1002/jcc.21334.AutoDock.

(39) Gfeller, D.; Grosdidier, A.; Wirth, M.; Daina, A.; Michielin, O.; Zoete, V. SwissTargetPrediction: A Web Server for Target Prediction of Bioactive Small Molecules. Nucleic Acids Res. 2014, 42 (W1), 32-38. https://doi.org/10.1093/nar/gku293.

(40) Parasuraman, S. Prediction of Activity Spectra for Substances. J. Pharmacol. Pharmacother. 2011, 2 (1), 52-53. https://doi.org/10.4103/0976-500X.77119.

(41) Ramaiah, K.; Srishailam, K.; Laxma Reddy, K.; Reddy, B. V.; Ramana Rao, G. Synthesis, Crystal and Molecular Structure, and Characterization of 2-((2Aminopyridin-3-YI)Methylene)-N-Ethylhydrazinecarbothioamide Using Spectroscopic ( $1 \mathrm{H}$ and $13 \mathrm{C}$ NMR, FT-IR, FT-Raman, UV-Vis) and DFT Methods and Evaluation of Its Anticancer Activit. J. Mol. Struct. 2019, 1184, 405-417. https://doi.org/10.1016/j.molstruc.2019.02.060.

(42) Rachedi, K. O.; Ouk, T. S.; Bahadi, R.; Bouzina, A.; Djouad, S. E.; Bechlem, 
K.; Zerrouki, R.; Ben Hadda, T.; Almalki, F.; Berredjem, M. Synthesis, DFT and POM Analyses of Cytotoxicity Activity of $\alpha$-Amidophosphonates Derivatives: Identification of Potential Antiviral O,O-Pharmacophore Site. J. Mol. Struct. 2019, 1197, 196-203. https://doi.org/10.1016/j.molstruc.2019.07.053.

(43) Kusumaningsih, T.; Prasetyo, W. E.; Firdaus, M. A Greatly Improved Procedure for the Synthesis of an Antibiotic-Drug Candidate 2,4Diacetylphloroglucinol over Silica Sulphuric Acid Catalyst: Multivariate Optimisation and Environmental Assessment Protocol Comparison by Metrics. RSC Adv. 2020, 10 (53), 31824-31837. https://doi.org/10.1039/D0RA05424K.

(44) Vistoli, G.; Pedretti, A.; Testa, B. Assessing Drug-Likeness - What Are We Missing? Drug Discov. Today 2008, 13 (7-8), 285-294. https://doi.org/10.1016/j.drudis.2007.11.007.

(45) Lipinski, C. A.; Lombardo, F.; Dominy, B. W.; Feeney, P. J. Experimental and Computational Approaches to Estimate Solubility and Permeability in Drug Discovery and Development Settings. Adv. Drug Deliv. Rev. 2012, 64 (SUPPL.), 4-17. https://doi.org/10.1016/j.addr.2012.09.019.

(46) Ortega, J. T.; Serrano, M. L.; Jastrzebska, B. Class a G Protein-Coupled Receptor Antagonist Famotidine as a Therapeutic Alternative against SARSCoV2: An in Silico Analysis. Biomolecules 2020, 10 (6), 1-19. https://doi.org/10.3390/biom10060954.

(47) Keiser, M. J.; Setola, V.; Irwin, J. J.; Laggner, C.; Abbas, A. I.; Hufeisen, S. J.; Jensen, N. H.; Kuijer, M. B.; Matos, R. C.; Tran, T. B.; Whaley, R.; Glennon, R. A.; Hert, J.; Thomas, K. L. H.; Edwards, D. D.; Shoichet, B. K.; Roth, B. L. Predicting New Molecular Targets for Known Drugs. Nature 2009, 462 (7270), 175-181. https://doi.org/10.1038/nature08506.

(48) Ghosh, R.; Chakraborty, A.; Biswas, A.; Chowdhuri, S. Evaluation of Green Tea Polyphenols as Novel Corona Virus (SARS CoV-2) Main Protease (Mpro) Inhibitors-an in Silico Docking and Molecular Dynamics Simulation Study. J. Biomol. Struct. Dyn. 2020, 0 (0), 1-13. https://doi.org/10.1080/07391102.2020.1779818.

(49) Huynh, T.; Wang, H.; Luan, B. In Silico Exploration of Molecular Mechanism and Potency Ranking of Clinically Oriented Drugs for Inhibiting SARS-CoV-2's Main Protease. 2020. https://doi.org/10.26434/chemrxiv.12045549.

(50) Koulgi, S.; Jani, V.; Uppuladinne, M.; Sonavane, U.; Nath, A. K.; Darbari, H.; Joshi, R. Drug Repurposing Studies Targeting SARS-CoV-2: An Ensemble Docking Approach on Drug Target 3C-like Protease (3CLpro). J. Biomol. Struct. Dyn. 2020, 0 (0), 1-21. https://doi.org/10.1080/07391102.2020.1792344.

(51) Zhang, L.; Lin, D.; Sun, X.; Curth, U.; Drosten, C.; Sauerhering, L.; Becker, S.; Rox, K.; Hilgenfeld, R. Crystal Structure of SARS-CoV-2 Main Protease Provides a Basis for Design of Improved a-Ketoamide Inhibitors. Science (80-. ). 2020, 368 (6489), 409-412. https://doi.org/10.1126/science.abb3405.

(52) Flores-Holguín, N.; Frau, J.; Glossman-Mitnik, D. Chemical Reactivity 
Properties, Drug-Likeness Features and Bioactivity Scores of the Cholecystokinin Peptide Hormone. Comput. Mol. Biosci. 2019, 09 (02), 41-47. https://doi.org/10.4236/cmb.2019.92004.

(53) Hiremath, S. M.; Patil, A. S.; Hiremath, C. S.; Basangouda, M.; Khemalapure, S. S.; Patil, N. R.; Radder, S. B.; Armaković, S. J.; Armaković, S. Structural, Spectroscopic Characterization of 2-(5-Methyl-1-Benzofuran-3-YI) Acetic Acid in Monomer, Dimer and Identification of Specific Reactive, Drug Likeness Properties: Experimental and Computational Study. J. Mol. Struct. 2019, 1178 (February 2019), 1-17. https://doi.org/10.1016/j.molstruc.2018.10.007.

(54) Panicker, C. Y.; Varghese, H. T.; Manjula, P. S.; Sarojini, B. K.; Narayana, B.; War, J. A.; Srivastava, S. K.; Van Alsenoy, C.; Al-Saadi, A. A. FT-IR, HOMOLUMO, NBO, MEP Analysis and Molecular Docking Study of 3-Methyl-4-\{(E)[4-(Methylsulfanyl)-Benzylidene]Amino\}1H-1,2,4-Triazole-5(4H)-Thione. Spectrochim. Acta - Part A Mol. Biomol. Spectrosc. 2015, 151, 198-207. https://doi.org/10.1016/j.saa.2015.06.076.

(55) Kamboj, V. P. Herbal Medicine. Curr. Sci. 2000, 78 (1), 35-39. https://doi.org/10.3138/9781487589264-044.

(56) Ganjhu, R. K.; Mudgal, P. P.; Maity, H.; Dowarha, D.; Devadiga, S.; Nag, S.; Arunkumar, G. Herbal Plants and Plant Preparations as Remedial Approach for Viral Diseases. VirusDisease 2015, 26 (4), 225-236. https://doi.org/10.1007/s13337-015-0276-6.

(57) Vijayakumar, B. G.; Ramesh, D.; Joji, A.; Jayachandra prakasan, J.; Kannan, T. In Silico Pharmacokinetic and Molecular Docking Studies of Natural Flavonoids and Synthetic Indole Chalcones against Essential Proteins of SARS-CoV-2. Eur. J. Pharmacol. 2020, 886 (July), 173448. https://doi.org/10.1016/j.ejphar.2020.173448.

(58) Muchtaridi, M.; Fauzi, M.; Khairul Ikram, N. K.; Mohd Gazzali, A.; Wahab, H. A. Natural Flavonoids as Potential Angiotensin-Converting Enzyme 2 Inhibitors for Anti-SARS-CoV-2. Molecules 2020, 25 (17), 3980. https://doi.org/10.3390/molecules25173980.

(59) Ryu, Y. B.; Jeong, H. J.; Kim, J. H.; Kim, Y. M.; Park, J. Y.; Kim, D.; Naguyen, T. T. H.; Park, S. J.; Chang, J. S.; Park, K. H.; Rho, M. C.; Lee, W. S. Biflavonoids from Torreya Nucifera Displaying SARS-CoV 3CLpro Inhibition. Bioorganic Med. Chem. 2010, 18 (22), 7940-7947. https://doi.org/10.1016/j.bmc.2010.09.035.

(60) Fan, W.; Qian, S.; Qian, P.; Li, X. Antiviral Activity of Luteolin against Japanese Encephalitis Virus. Virus Res. 2016, 220, 112-116. https://doi.org/10.1016/j.virusres.2016.04.021.

(61) Bai, L.; Nong, Y.; Shi, Y.; Liu, M.; Yan, L.; Shang, J.; Huang, F.; Lin, Y.; Tang, H. Luteolin Inhibits Hepatitis B Virus Replication through Extracellular SignalRegulated Kinase-Mediated Down-Regulation of Hepatocyte Nuclear Factor 4a Expression. Mol. Pharm. 2016, 13 (2), 568-577. https://doi.org/10.1021/acs.molpharmaceut.5b00789. 
(62) Kim, S. H.; Shin, K. J.; Kim, D.; Kim, Y. H.; Han, M. S.; Lee, T. G.; Kim, E.; Ryu, S. H.; Suh, P. G. Luteolin Inhibits the Nuclear Factor-KB Transcriptional Activity in Rat-1 Fibroblasts. Biochem. Pharmacol. 2003, 66 (6), 955-963. https://doi.org/10.1016/S0006-2952(03)00465-9.

(63) Lv, X.; Quu, M.; Chen, D.; Zheng, N.; Jin, Y.; Wu, Z. Apigenin Inhibits Enterovirus 71 Replication through Suppressing Viral IRES Activity and Modulating Cellular JNK Pathway. Antiviral Res. 2014, 109 (1), 30-41. https://doi.org/10.1016/j.antiviral.2014.06.004.

(64) Mehla, R.; Bivalkar-Mehla, S.; Chauhan, A. A Flavonoid, Luteolin, Cripples HIV-1 by Abrogation of Tat Function. PLoS One 2011, 6 (11). https://doi.org/10.1371/journal.pone.0027915.

(65) Nahmias, Y.; Goldwasser, J.; Casali, M.; Van Poll, D.; Wakita, T.; Chung, R. T.; Yarmush, M. L. Apolipoprotein B-Dependent Hepatitis C Virus Secretion Is Inhibited by the Grapefruit Flavonoid Naringenin. Hepatology 2008, 47 (5), 1437-1445. https://doi.org/10.1002/hep.22197.

(66) Pohjala, L.; Utt, A.; Varjak, M.; Lulla, A.; Merits, A.; Ahola, T.; Tammela, P. Inhibitors of Alphavirus Entry and Replication Identified with a Stable Chikungunya Replicon Cell Line and Virus-Based Assays. PLoS One 2011, 6 (12). https://doi.org/10.1371/journal.pone.0028923.

(67) Lin, Y. M.; Anderson, H.; Flavin, M. T.; Pai, Y. H. S.; Mata-Greenwood, E.; Pengsuparp, T.; Pezzuto, J. M.; Schinazi, R. F.; Hughes, S. H.; Chen, F. C. In Vitro Anti-HIV Activity of Biflavonoids Isolated from Rhus Succedanea and Garcinia Multiflora. J. Nat. Prod. 1997, 60 (9), 884-888. https://doi.org/10.1021/np9700275.

(68) Castrillo, M.; Córdova, T.; Cabrera, G.; Rodríguez-Ortega, M. Effect of Naringenin, Hesperetin and Their Glycosides Forms on the Replication of the 17D Strain of Yellow Fever Virus (Efecto de La Naringenina, Hesperetina y Sus Formas Glicosidadas Sobre La Replicación de La Cepa 17D Del Virus de La Fiebre Amarilla). Av. en Biomed. 2015, No. 2, 69-78.

(69) Tutunchi, H.; Naeini, F.; Ostadrahimi, A.; Hosseinzadeh-Attar, M. J. Naringenin, a Flavanone with Antiviral and Anti-Inflammatory Effects: A Promising Treatment Strategy against COVID-19. Phyther. Res. 2020, No. April, 1-11. https://doi.org/10.1002/ptr.6781.

(70) Yang, H.; Yang, M.; Ding, Y.; Liu, Y.; Lou, Z.; Zhou, Z.; Sun, L.; Mo, L.; Ye, S.; Pang, H.; Gao, G. F.; Anand, K.; Bartlam, M.; Hilgenfeld, R.; Rao, Z. The Crystal Structures of Severe Acute Respiratory Syndrome Virus Main Protease and Its Complex with an Inhibitor. Proc. Natl. Acad. Sci. U. S. A. 2003, 100 (23), 13190-13195. https://doi.org/10.1073/pnas.1835675100.

(71) Zhao, Q.; Li, S.; Xue, F.; Zou, Y.; Chen, C.; Bartlam, M.; Rao, Z. Structure of the Main Protease from a Global Infectious Human Coronavirus, HCoV-HKU1. J. Virol. 2008, 82 (17), 8647-8655. https://doi.org/10.1128/jvi.00298-08.

(72) Ferreira De Freitas, R.; Schapira, M. A Systematic Analysis of Atomic ProteinLigand Interactions in the PDB. Medchemcomm 2017, 8 (10), 1970-1981. 
https://doi.org/10.1039/c7md00381a.

(73) Taylor, A. R. D.; Maccoss, M.; Lawson, A. D. G. Supporting Information Rings in Drugs. J. Med. Chem. 2014, 57, 5845-5859.

(74) Ritchie, T. J.; Macdonald, S. J. F. Physicochemical Descriptors of Aromatic Character. J Med Chem 2014, 57 (17), 7206-7215. https://doi.org/10.1021/jm500515d.

(75) Nittinger, E.; Inhester, T.; Bietz, S.; Meyder, A.; Schomburg, K. T.; Lange, G.; Klein, R.; Rarey, M. Large-Scale Analysis of Hydrogen Bond Interaction Patterns in Protein-Ligand Interfaces. J. Med. Chem. 2017, 60 (10), 42454257. https://doi.org/10.1021/acs.jmedchem.7b00101.

(76) Steiner, T. The Hydrogen Bond in the Solid State. Angew. Chemie Int. Ed. 2002, 41 (1), 48-76. https://doi.org/10.1002/15213773(20020104)41:1<48::AID-ANIE48>3.0.CO;2-U.

(77) Musah, R. A.; Jensen, G. M.; Rosenfeld, R. J.; McRee, D. E.; Goodin, D. B.; Bunte, S. W. Variation in Strength of an Unconventional C-H to O Hydrogen Bond in an Engineered Protein Cavity. J. Am. Chem. Soc. 1997, 119 (38), 9083-9084. https://doi.org/10.1021/ja9716766.

(78) Pierce, A. C.; Sandretto, K. L.; Bemis, G. W. Kinase Inhibitors and the Case for $\mathrm{CH} \cdots \mathrm{O}$ Hydrogen Bonds in Protein-Ligand Binding. Proteins Struct. Funct. Genet. 2002, 49 (4), 567-576. https://doi.org/10.1002/prot.10259.

(79) Dougherty, D. A. The Cation-m Interaction. Acc. Chem. Res. 2013, 46 (4), 885-893. https://doi.org/10.1021/ar300265y.

(80) Mengist, H. M.; Fan, X.; Jin, T. Designing of Improved Drugs for COVID-19: Crystal Structure of SARS-CoV-2 Main Protease Mpro. Signal Transduct. Target. Ther. 2020, 5 (1), 2-3. https://doi.org/10.1038/s41392-020-0178-y. 


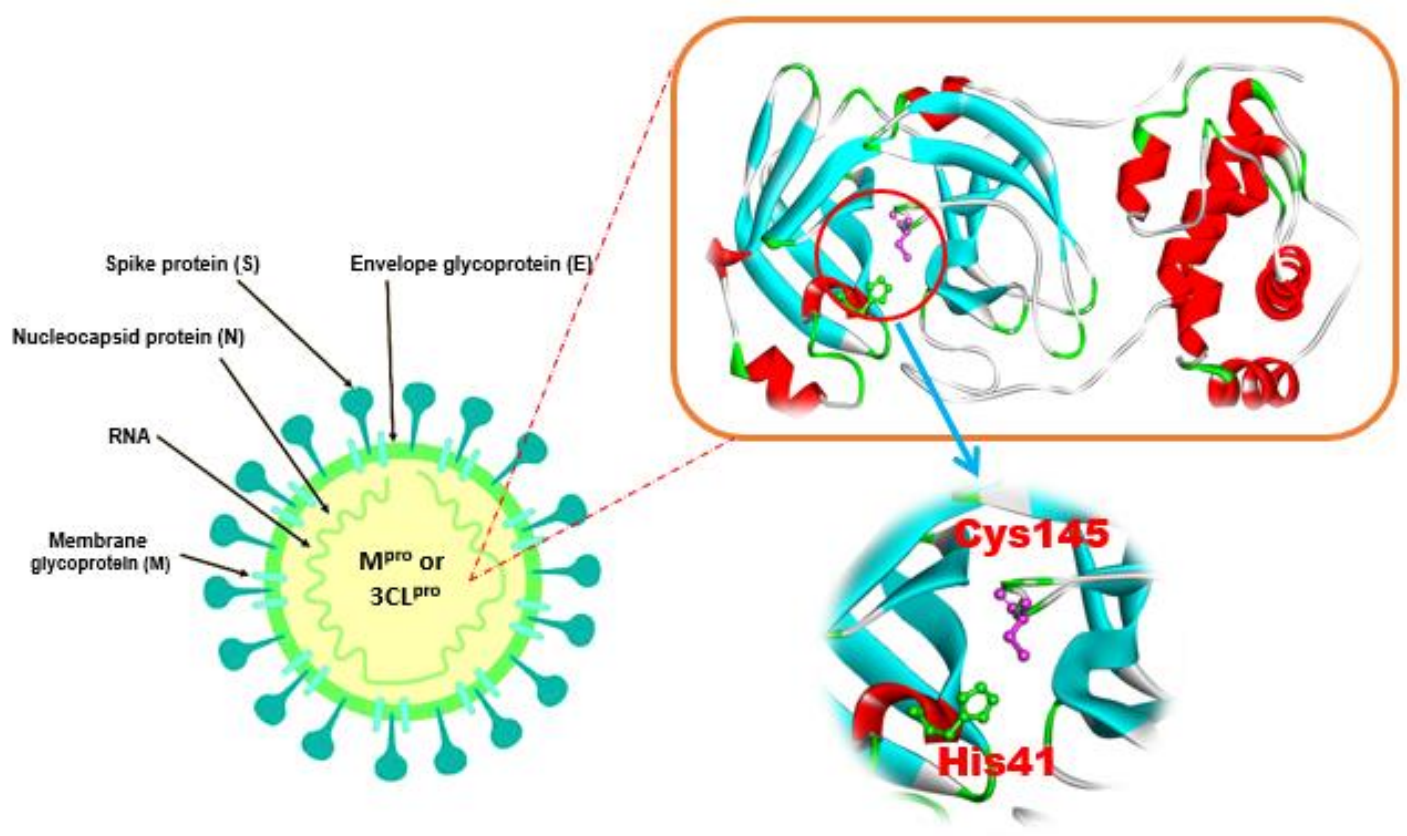

Figure 1. Overview of the structure of SARS-CoV-2 and $3 C L^{\text {pro }}$ enzyme of SARSCoV-2 displaying residues Cys145 and His41 as the part of the catalytic dyad 


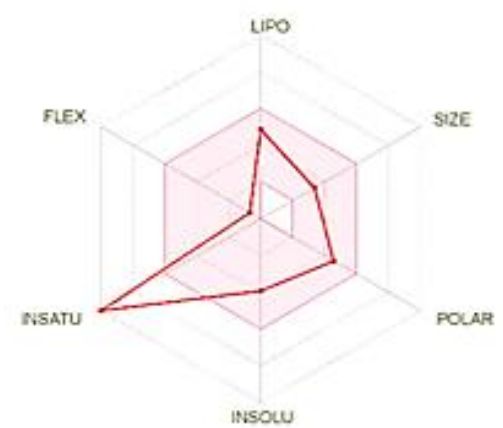

Apigenin

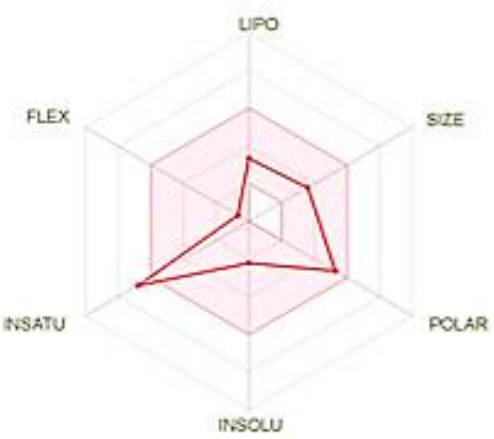

Catechin

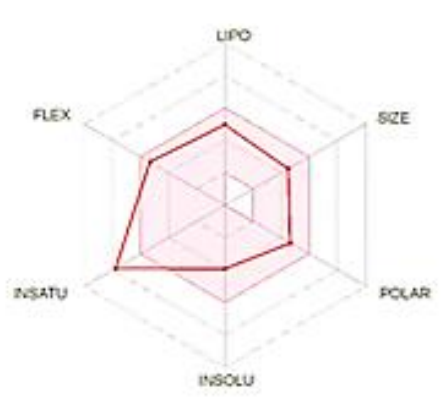

Curcumin

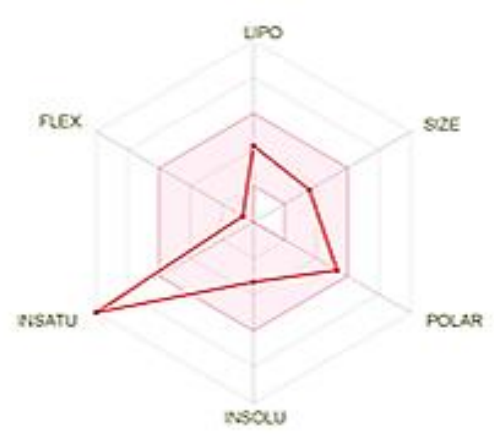

Kaempferol

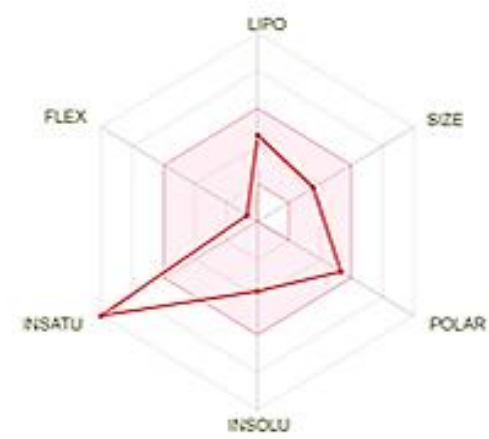

Taxifolin

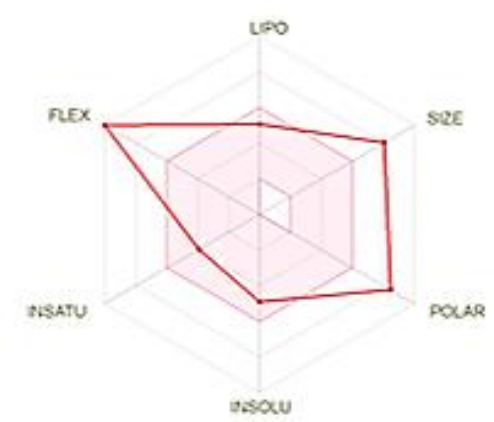

N3

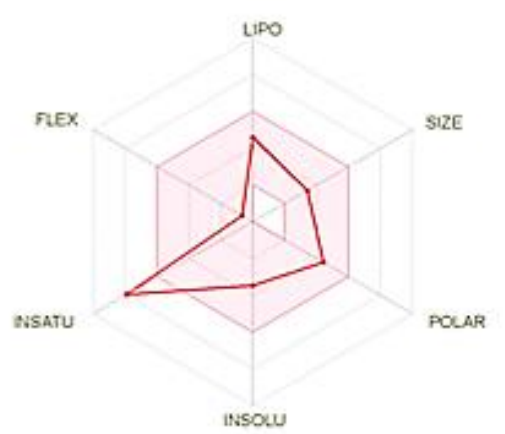

Naringenin

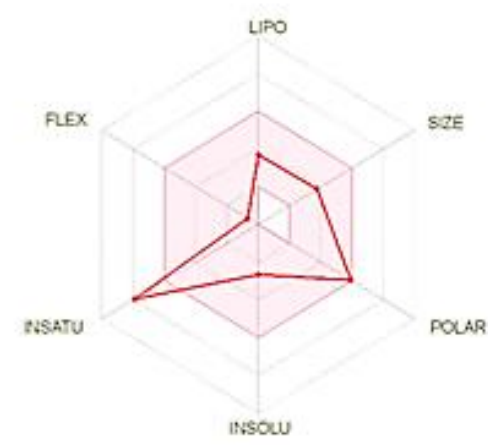

Luteolin

Figure 2. Bioavailability radar plot of the top 7 bioactive phytochemicals from several medicinal plants used in Jamu along with control (N3) using SwissADME server (http://www.swissadme.ch/). The colour space is the suitable physiochemical space for oral bioavailability. LIPO Lipophility: $-0.7<$ XLOGP3 < p5.0. SIZE: $150 \mathrm{~g} / \mathrm{mol}:<$ $\mathrm{MW}<500 \mathrm{~g} / \mathrm{mol}$. POLAR (Polarity): $20 \AA^{2}<$ TPSA $<130 \AA^{2}$. INSOLU (insolubility): $0<$ Log $S(E S O L)<6$. INSATU (insaturation): $0.25<$ Fraction Csp $^{3}<1$. FLEX (Flexibity): $0<$ Num. rotatable bonds $<9$ 

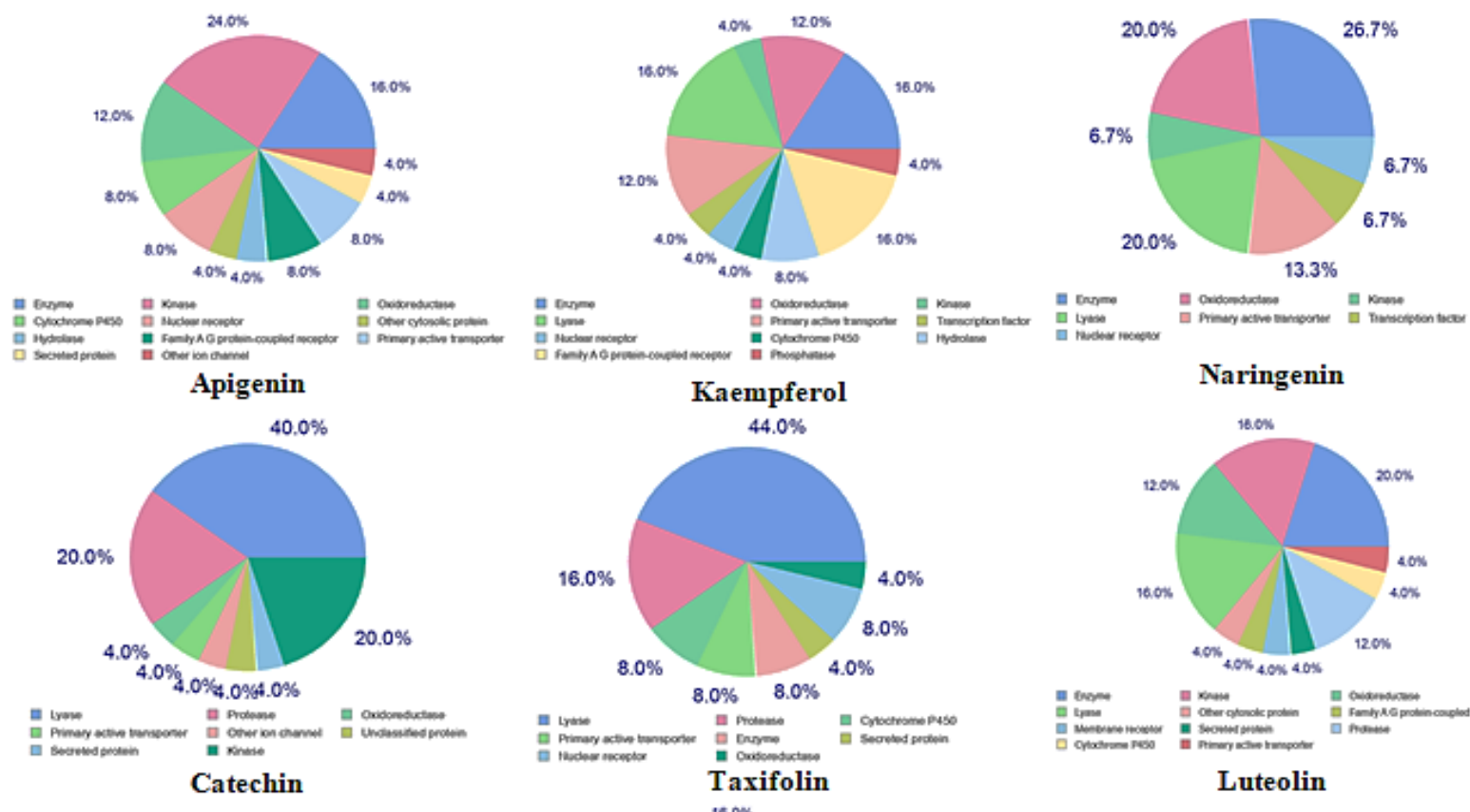

Naringenin
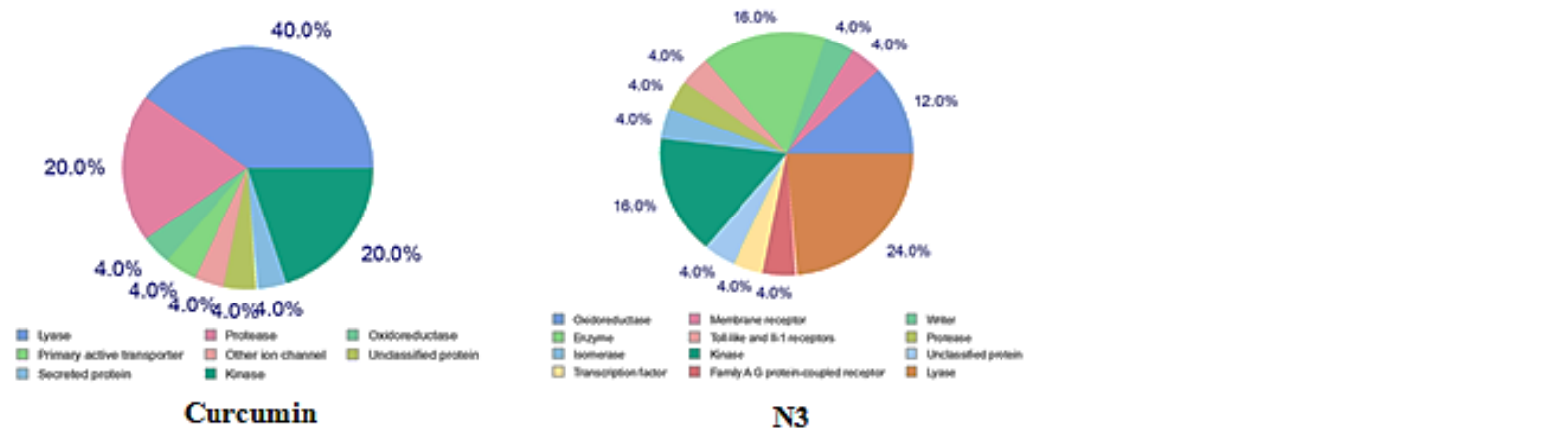

Figure 3. Top-25 of Target Predicted for the top bioactive phytochemicals from several medicinal plants used in Jamu and control against $3 \mathrm{CL}^{\text {pro }}$ of SARS-CoV-2 


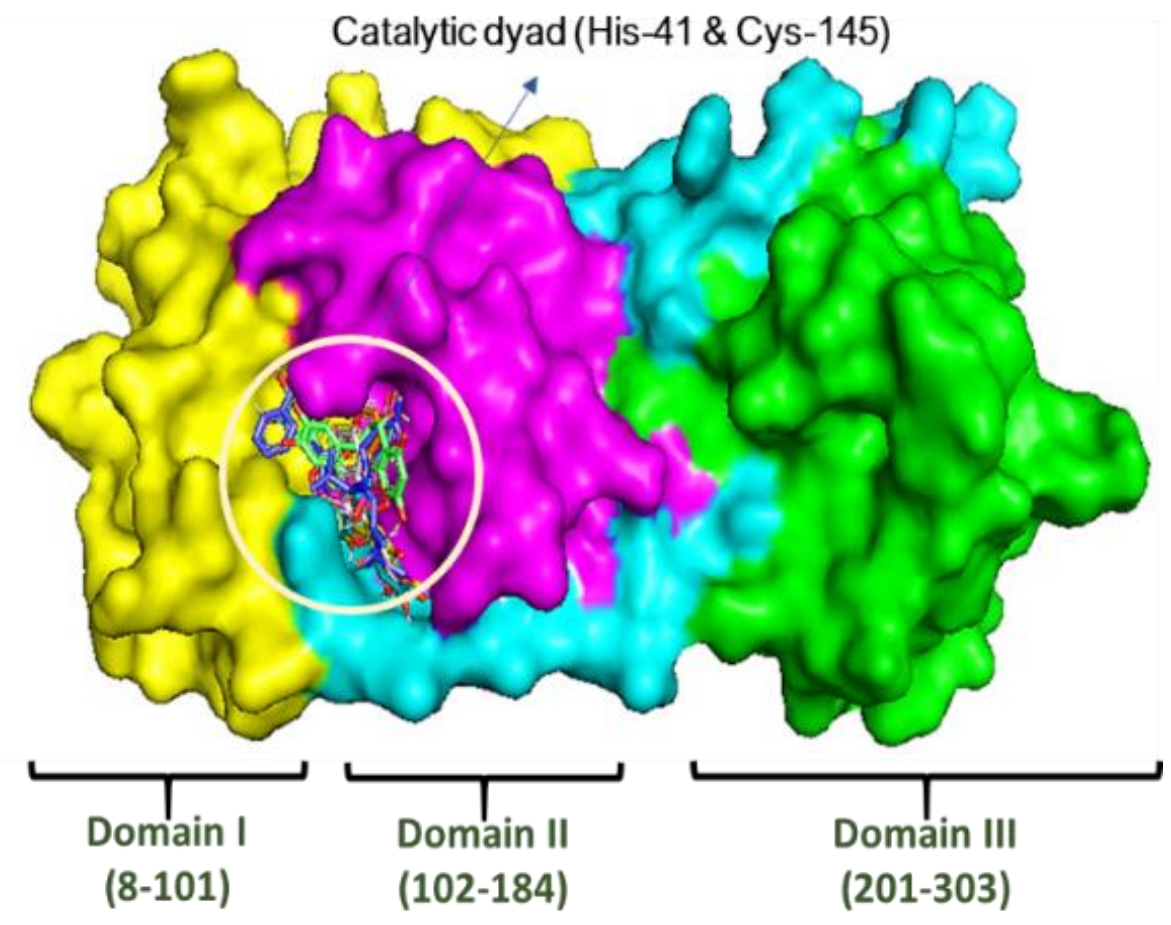

Figure 4. Surface representation showing the interaction of Apigenin, Catechin, Curcumin, Kaempferol, Luteolin, Naringenin, Taxifolin, and N3 at the substratebinding region of 3CLpro of SARS-CoV-2 

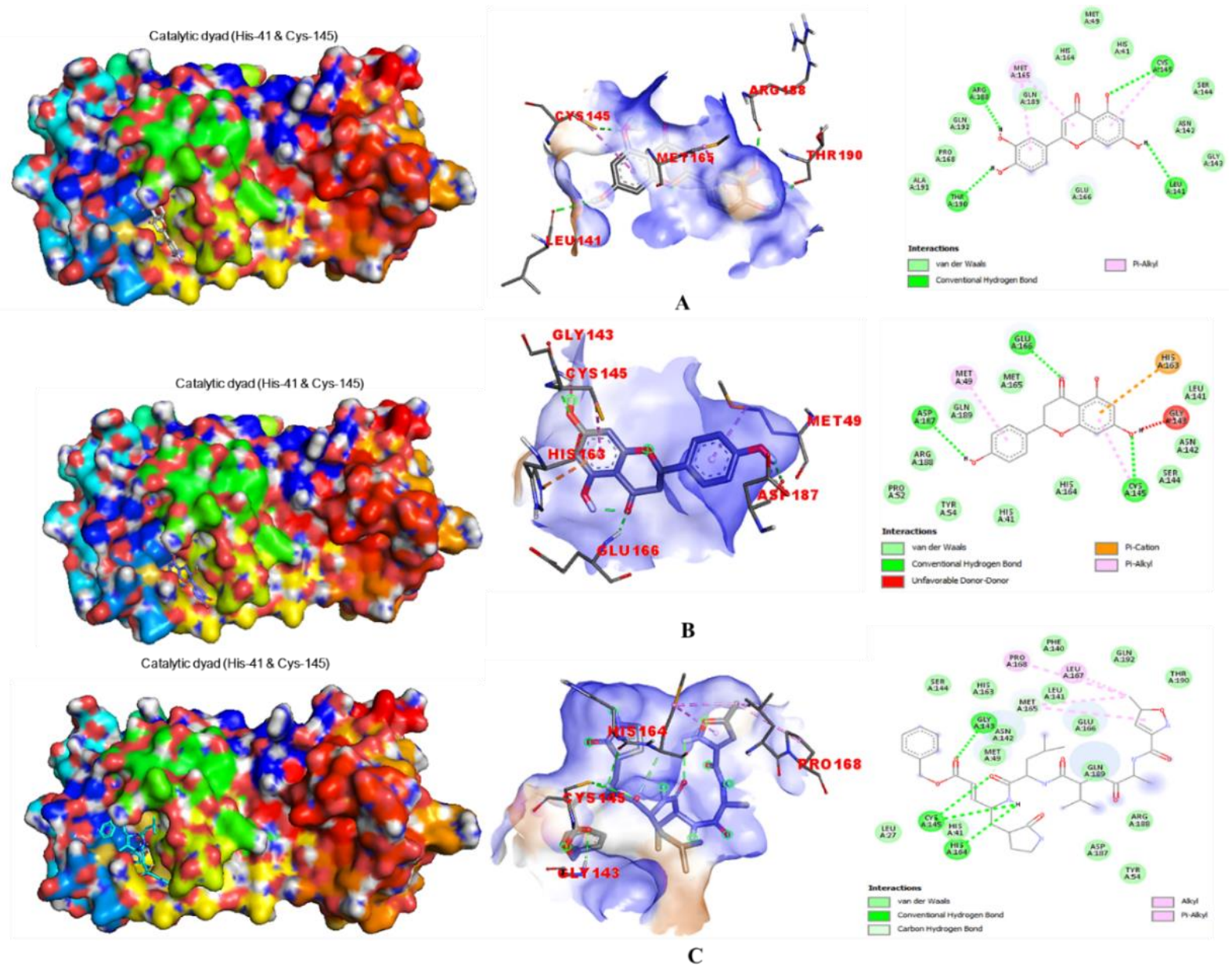

Figure 5. Binding poses and molecular interactions between Luteolin (A), Naringenin $(B)$, and N3 (C) with $3 C^{\text {pro }}$ of SARS-CoV-2 


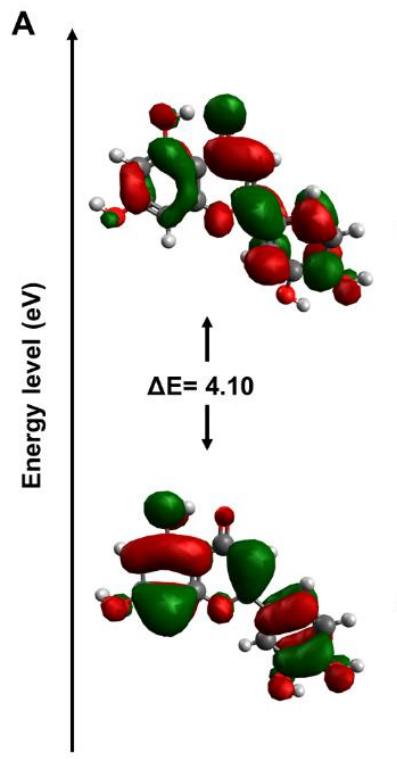

Luteolin

B

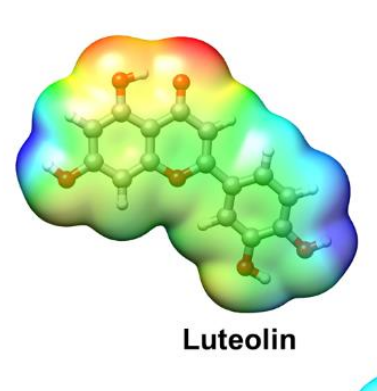

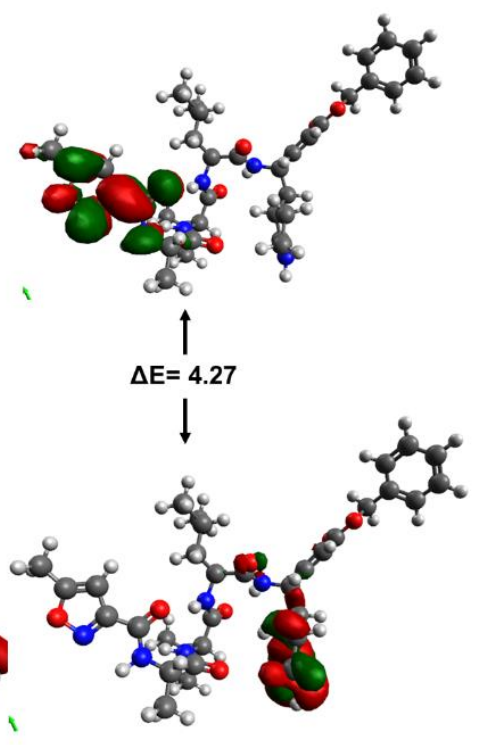

N3

Naringenin

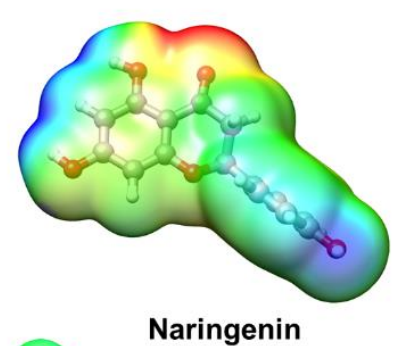

Naringenin

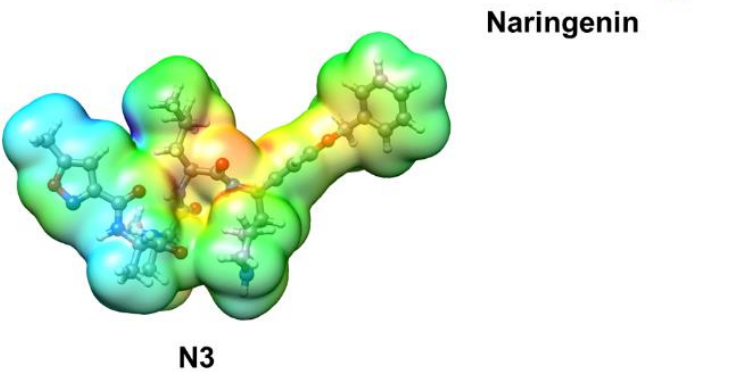

N3

Figure 6. HOMO and LUMO plots of compound Luteolin and Naringenin. Positive and negative phases are shown in red and green colours, respectively $(\mathbf{A})$. MEP maps of compound Luteolin and Naringenin. The values of electrostatic potential are illustrated with different colours which are increases in the order of red < orange $<$ yellow < green < blue $(\mathbf{B})$ 


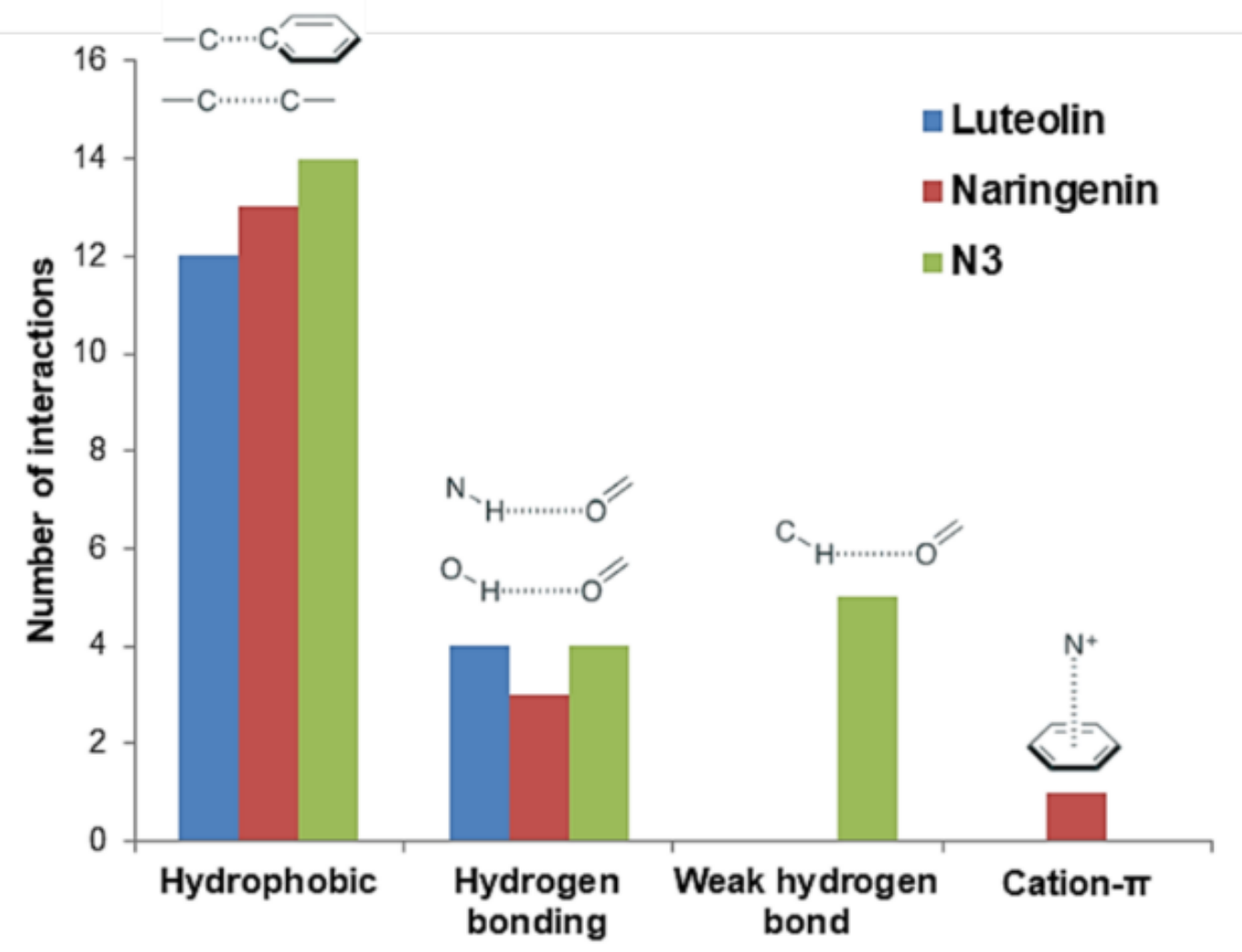

Figure 7. Frequency distribution of interactions observed in lead compounds (Luteolin and Naringenin) and N3 complexes 


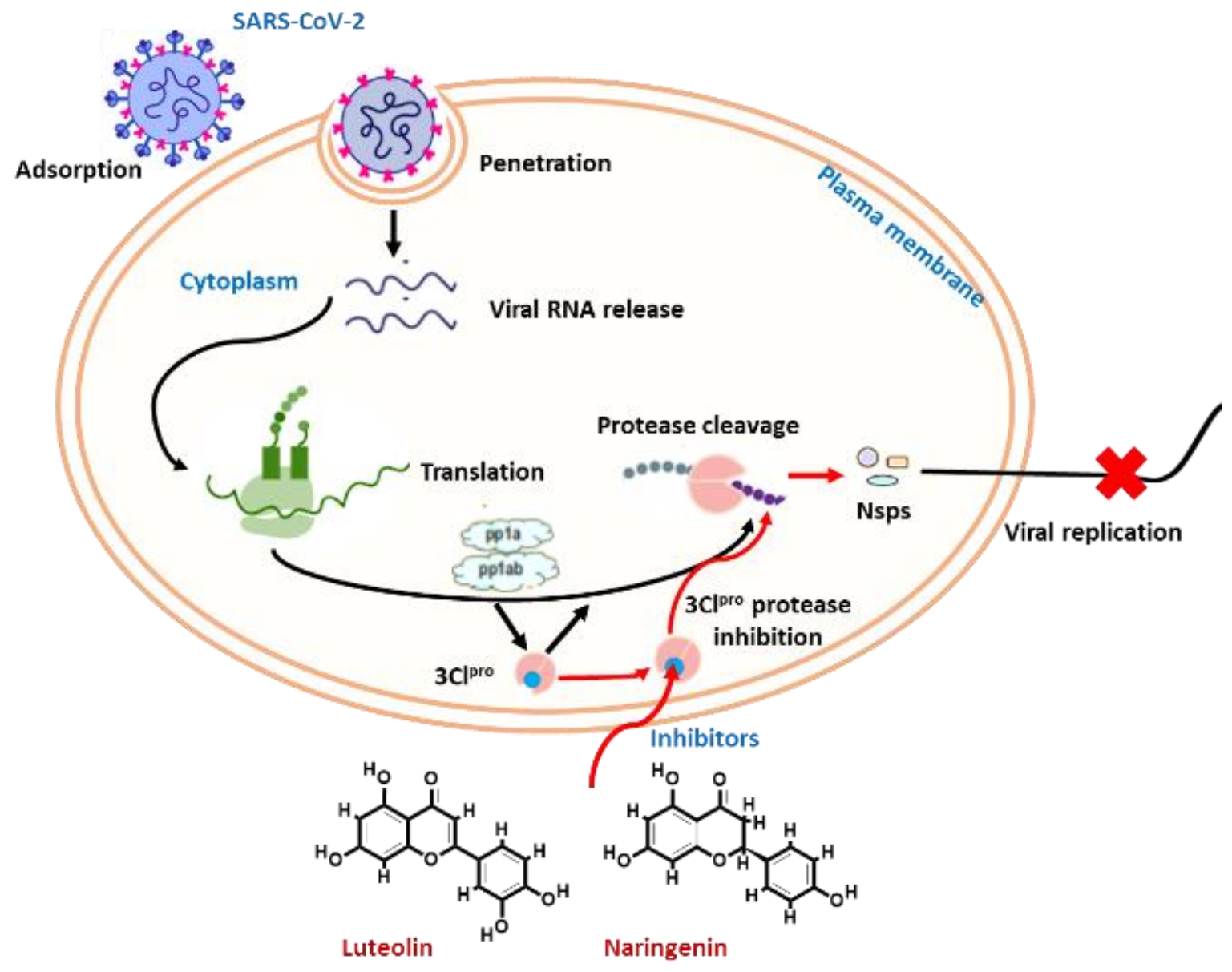

Figure 8. A plausible mechanism of Luteolin and Naringenin prevent the replication of SARS-CoV-2 
Table 1. Binding affinities of the top bioactive phytochemicals from several medicinal plants used in Jamu and control against 3CLpro of SARS-CoV-2

\begin{tabular}{|c|c|c|c|c|c|c|}
\hline No & $\begin{array}{c}\text { Bioactive } \\
\text { phytochemicals }\end{array}$ & $\begin{array}{l}\text { PubChem } \\
\text { CID }\end{array}$ & $\begin{array}{l}\text { Molecular } \\
\text { Formula }\end{array}$ & $\begin{array}{c}\text { Plant } \\
\text { Species } \\
\text { (Local } \\
\text { name) }\end{array}$ & Family & $\begin{array}{c}\text { Binding } \\
\text { energy } \\
\text { (Kcal } / \text { mol) }\end{array}$ \\
\hline 1 & Aloin A & 9866696 & $\mathrm{C}_{21} \mathrm{H}_{22} \mathrm{O}_{9}$ & $\begin{array}{l}\text { Aloe vera } \\
\text { (Lidah } \\
\text { buaya) }\end{array}$ & Xanthorrhoeaceae & -8.0 \\
\hline 2 & Apigenin & 5280443 & $\mathrm{C}_{15} \mathrm{H}_{10} \mathrm{O}_{5}$ & $\begin{array}{c}\text { Tamarindus } \\
\text { indica } \\
\text { (Asem jawa) }\end{array}$ & Fabaceae & -7.8 \\
\hline 3 & Catechin & 73160 & $\mathrm{C}_{21} \mathrm{H}_{22} \mathrm{O}_{9}$ & $\begin{array}{c}\text { Tamarindus } \\
\text { indica } \\
\text { (Asem jawa) }\end{array}$ & Fabaceae & -7.5 \\
\hline 4 & Curcumin & 969516 & $\mathrm{C}_{21} \mathrm{H}_{20} \mathrm{O}_{6}$ & $\begin{array}{c}\text { Curcuma } \\
\text { domestica } \\
\text { (Kunyit) } \\
\text { Citrus }\end{array}$ & Zingeiberaceae & -7.2 \\
\hline 5 & Hesperidin & 10621 & $\mathrm{C}_{28} \mathrm{H}_{34} \mathrm{O}_{15}$ & $\begin{array}{l}\text { aurantifolia } \\
\text { (Jeruk nipis) }\end{array}$ & Rutceae & -8.1 \\
\hline 6 & Kaempferol & 5280863 & $\mathrm{C}_{15} \mathrm{H}_{10} \mathrm{O}_{6}$ & $\begin{array}{l}\text { Foeniculum } \\
\text { vulgare } \\
\text { Miller (Adas) }\end{array}$ & Apiaceae & -7.8 \\
\hline 7 & Luteolin & 5280445 & $\mathrm{C}_{15} \mathrm{H}_{10} \mathrm{O}_{6}$ & $\begin{array}{c}\text { Tamarindus } \\
\text { indica } \\
\text { (Asem jawa) }\end{array}$ & Fabaceae & -7.4 \\
\hline 8 & Naringenin & 439246 & $\mathrm{C}_{15} \mathrm{H}_{12} \mathrm{O}_{5}$ & $\begin{array}{l}\text { Tamarindus } \\
\text { indica } \\
\text { (Asem jawa) }\end{array}$ & Fabaceae & -7.7 \\
\hline 9 & Naringin & 442428 & $\mathrm{C}_{27} \mathrm{H}_{32} \mathrm{O}_{14}$ & $\begin{array}{c}\text { aurantifolia } \\
\text { (Jeruk nipis) }\end{array}$ & Rutceae & -8.3 \\
\hline 10 & Procyanidins & 107876 & $\mathrm{C}_{30} \mathrm{H}_{26} \mathrm{O}_{13}$ & $\begin{array}{c}\text { Tamarindus } \\
\text { indica } \\
\text { (Asem jawa) }\end{array}$ & Fabaceae & -8.5 \\
\hline 11 & Taxifolin & 439533 & $\mathrm{C}_{15} \mathrm{H}_{12} \mathrm{O}_{7}$ & $\begin{array}{l}\text { Tamarindus } \\
\text { indica } \\
\text { (Asem jawa) }\end{array}$ & Fabaceae & -7.4 \\
\hline 12 & N3 (Control) & $4883311^{*}$ & $\mathrm{C}_{35} \mathrm{H}_{48} \mathrm{~N}_{6} \mathrm{O}_{8}$ & - & - & -7.5 \\
\hline
\end{tabular}


Table 2. Interacting amino acid residues of $3 \mathrm{CL}^{\text {pro }}$ of SARS-CoV-2 with the top 7 binding phytochemicals of several medicinal plants used in Jamu

\begin{tabular}{|c|c|c|c|}
\hline No. & Ligands & $\begin{array}{c}\text { Hydrogen } \\
\text { bonds }\end{array}$ & Interacted residues \\
\hline 1 & Apigenin & Ser144 & $\begin{array}{l}\text { His41*, Pro52, Tyr54, Met 49, Phe140, Leu141, Cys145, } \\
\text { His163, His164, Met165, Glu166, Asp187, Arg188, Gln189 }\end{array}$ \\
\hline 2 & Catechin & Gln189 & $\begin{array}{l}\text { His41*, Met49, Tyr54, Phe140, Leu141, Ser144, Cys 145, } \\
\text { His163, His164, Glu166, Val186, Asp187, Arg188 } \\
\text { His41*, Met49, Asn142, Ser144, Cys 145, His163, His164, }\end{array}$ \\
\hline 3 & Curcumin & Keu141, Gly143 & $\begin{array}{c}\text { Met165, Glu166, Leu167, Pro168, Asp187, Arg188, } \\
\text { Gln189, Thr190, Gln192 }\end{array}$ \\
\hline 4 & Kaempferol & $\begin{array}{l}\text { Ser144, Asp187, } \\
\text { Gln189 }\end{array}$ & $\begin{array}{c}\text { His41*, Tyr54, Met49, Leu141, Asn142, Cys145, Phe140, } \\
\text { His163, His164, Met165, Glu166, Arg188 }\end{array}$ \\
\hline 5 & Luteolin & $\begin{array}{l}\text { Cys } 145^{\star} \\
\text { Leu141, Arg189, } \\
\text { Thr190 }\end{array}$ & $\begin{array}{l}\text { His41*, Met49, Asn142, Gly143, Ser144, His164, Met165, } \\
\text { Glu166, Pro168, Gln189, Ala191, Gln192 }\end{array}$ \\
\hline 6 & Naringenin & $\begin{array}{l}\text { Cys } 145^{*} \text {, Glu166, } \\
\text { Asp187 }\end{array}$ & \multirow{3}{*}{$\begin{array}{c}\text { His41*, Met49, Pro52, Tyr54, Leu141, Asn142, Gly143, } \\
\text { Ser144, His163, His164, Met165, Arg188, Gln189 } \\
\text { His41*, Met49, Tyr54, Cys145, His164, Met165, Glu166, } \\
\text { Leu167, Pro168, Asp187, Arg188, Gln189, Ala191 } \\
\text { Leu27, His41*, Met49, Tyr54, Phe140, Leu141, Asn142, } \\
\text { Ser144, His163, Met165, Glu166, Leu167, Pro168, } \\
\text { Arg188, Gln189, Thr190, Gln192 }\end{array}$} \\
\hline 7 & Taxifolin & Thr190, Gln192 & \\
\hline 8 & $\begin{array}{c}\mathrm{N} 3 \\
\text { (Control) }\end{array}$ & $\begin{array}{l}\text { Gly143, Cys } 145^{\star} \\
\text { His } 164\end{array}$ & \\
\hline
\end{tabular}


Table 3. Part of the predicted antiviral activity spectra for Luteolin and Naringenin along with N3

\begin{tabular}{ccccccc}
\hline Ligands & \multicolumn{2}{c}{ Luteolin } & \multicolumn{2}{c}{ Naringenin } & \multicolumn{2}{c}{ N3 } \\
\hline Activity name & $\mathrm{Pa}$ & $\mathrm{Pi}$ & $\mathrm{Pa}$ & $\mathrm{Pi}$ & $\mathrm{Pi}$ & $\mathrm{Pa}$ \\
\hline Antiviral (Adenovirus) & 0.246 & 0.143 & 0.225 & 0.172 & 0.099 & - \\
Antiviral (CMV) & 0.215 & 0.142 & - & - & 0.114 & - \\
Antiviral (HIV) & 0.149 & 0.067 & - & - & 0.004 & 0.121 \\
Antiviral (Herpes) & 0.471 & 0.014 & 0.499 & 0.010 & 0.155 & - \\
Antiviral (Herpesvirus 3) & - & - & - & - & - & - \\
Antiviral (Influenza A) & - & - & - & - & 0.150 & 0.234 \\
Antiviral (Influenza) & 0.462 & 0.030 & 0.691 & 0.006 & 0.122 & - \\
Antiviral (Parainfluenza) & - & - & - & - & - & - \\
Antiviral (Picornavirus) & 0.279 & 0.263 & 0.300 & 0.227 & 0.162 & - \\
Antiviral (Poxvirus) & - & - & - & - & 0.176 & - \\
Antiviral (Rhinovirus) & - & - & 0.611 & 0.005 & 0.074 & 0.337 \\
Antiviral (Hepatitis C) & - & - & - & - & - & 0.119 \\
Antiviral (Hepatitis) & - & - & 0.113 & 0.080 & - & 0.136 \\
Antiviral (Hepatitis B) & 0.473 & 0.006 & 0.483 & 0.005 & - & - \\
\hline
\end{tabular}


Table 4. Calculated quantum chemical parameters for Luteolin and Naringenin along with N3

\begin{tabular}{|c|c|c|c|}
\hline Chemical reactivity indices & Luteolin & Naringenin & N3 \\
\hline Еномо (eV) & -6.23 & -6.33 & -6.50 \\
\hline Elumo (eV) & -2.13 & -1.48 & -2.23 \\
\hline Energy gap $\left(\Delta \mathrm{E}_{\text {gap }}\right)=\left(\right.$ Е $\left._{\text {LUмо }}-\mathrm{E}_{\text {номо }}\right)(\mathrm{eV})$ & 4.10 & 4.85 & 4.27 \\
\hline Ionisation potential $(\mathrm{I})=-\mathrm{E}_{\text {номо }}(\mathrm{eV})$ & 6.23 & 6.33 & 6.50 \\
\hline Electron affinity $(A)=-E_{\text {LUMO }}(e V)$ & 2.13 & 1.48 & 2.23 \\
\hline Electronegativity $(\mathrm{X})=-($ Еномо-ELUMо $) / 2(\mathrm{eV})$ & 2.05 & 2.42 & 2.14 \\
\hline Chemical potential $(\mu)=1 / 2($ ELUмо + Еномо $)(e V)$ & -4.18 & -3.90 & -4.36 \\
\hline Global hardness $(\eta)=1 / 2($ ĔUмо - Еномо $(\mathrm{eV})$ & 2.05 & 2.42 & 2.14 \\
\hline Softness chemical softness $(S)=1 / 2 \eta(e V)^{-1}$ & 1.03 & 1.21 & 1.07 \\
\hline Electrophilicity index electrophilicity index $(\omega)=\mu^{2} / 2 \eta(\psi)$ & 4.26 & 3.14 & 4.46 \\
\hline
\end{tabular}

